\title{
Using Habitat Equivalency Analysis to Assess the Cost Effectiveness of Restoration Outcomes in Four Institutional Contexts
}

\author{
Scemama Pierre ${ }^{1 ? *}$, Levrel Harold ${ }^{1,2}$ \\ ${ }^{1}$ IFREMER, UMR AMURE, Marine Econ Unit, ZI Pointe Diable, F-29280 Plouzane, France. \\ ${ }^{2}$ AgroParisTech, UMR CIRED, F-94736 Nogent Sur Marne, France. \\ * Corresponding author : Pierre Scenama, email address : scemama.p@gmail.com; \\ harold.levrel@agroparistech.fr
}

\begin{abstract}
:
At the national level, with a fixed amount of resources available for public investment in the restoration of biodiversity, it is difficult to prioritize alternative restoration projects. One way to do this is to assess the level of ecosystem services delivered by these projects and to compare them with their costs. The challenge is to derive a common unit of measurement for ecosystem services in order to compare projects which are carried out in different institutional contexts having different goals (application of environmental laws, management of natural reserves, etc.). This paper assesses the use of habitat equivalency analysis (HEA) as a tool to evaluate ecosystem services provided by restoration projects developed in different institutional contexts. This tool was initially developed to quantify the level of ecosystem services required to compensate for non-market impacts coming from accidental pollution in the US. In this paper, HEA is used to assess the cost effectiveness of several restoration projects in relation to different environmental policies, using case studies based in France. Four case studies were used: the creation of a market for wetlands, public acceptance of a port development project, the rehabilitation of marshes to mitigate nitrate loading to the sea, and the restoration of streams in a protected area. Our main conclusion is that HEA can provide a simple tool to clarify the objectives of restoration projects, to compare the cost and effectiveness of these projects, and to carry out trade-offs, without requiring significant amounts of human or technical resources.
\end{abstract}

Keywords : Wetland restoration, Equivalency tool, Ecosystem services, Cost effectiveness 


\section{Introduction}

According to economics, the welfare of populations at a given time is a function of the utility released by the consumption of goods and services available at this time E(Ramsey, 1928). Goods and services are produced using a certain amount of capital as input through a production process. Future consumption and future welfare are thus a function of the actual stocks of capital (Mäler et al., 2008).

There are different types of capital involved in the production function: manufactured capital (material goods), human capital (individuals working capacity) and natural capital. Natural capital is constituted of the limited stocks of natural resources, physical and biological, that yield the flow of goods and services from ecosystems (Costanza and Daly, 1992).

In the context of project planning, economists are supposed to assess what is the best allocation of resources among alternative scenarios of substitution between natural capital, human capital and manufactured capital. This assessment requires a unit of equivalency. If manufactured and human capital have long been assessed in monetary terms, it is still in debate for natural capital. This debate is largely associated to the debate between weak sustainability (strong substitutability between natural capital and manufactured capital) and strong sustainability (weak substitutability between natural capital and manufactured capital) (Stern, 1997; Ekins et al., 2003; Bithas et al., 2011). Standard environmental economy considers that the different types of capital are substitutable (Pearce and Atkinson, 1993). As a result, it is focused on the monetary value of natural capital in comparison with the monetary value of manufactured capital. In this way, monetary valuation provides economic units of equivalency allowing to measure the benefits provided by alternative scenarios regarding the substitution of one category of capital by another. Ecological economy contests this position and argues that substitution is only possible at the margin and that there is a portion of natural capital that is essential to human survival and for which there is no adequate substitute, defining critical natural capital (Ekins et al., 2003). Furthermore, it denounces the limits of monetary valuation which are of three types: (1) methodological limits to value ecological services due to non-commercial use value or non-use value (Heal, 2000); (2) limits to respect all the constraints of strong sustainability, even when all externalities are internalised (Bithas et al., 2011) ; (3) the lack of institutional contextualization of monetary values that limit their informative scope (Norgaard and Bode, 1998 ; Vatn 2010). 
The idea that there is a minimum level of natural capital necessary to support human welfare seems more and more obvious to policy makers, which is why there is a growing number of institutional frames fixing strong ecological objectives, for example through European environmental directives: Water Framework Directive or the Marine Strategy Framework Directive (Good Ecological States), Natura 2000 Directive (Protected Species and Habitat Lists), Environmental Impact Studies Directive (Avoid-Reduce-Compensate ecological impacts), Environmental Liability Directive (no net loss of biodiversity and ecological services). They fix minimum quality standards in ecological terms for aquatic ecosystems, implying reduction of pressures and restoration of damaged ecosystems. In this context, the challenge for ecological economists is to be able to provide biophysical units of equivalency which are substitutable enough to provide a simplified picture of what the level of natural capital is. The aim of this paper is to assess how it is possible to use the Habitat Equivalency Analysis (HEA) to evaluate restoration projects developed in alternative institutional contexts. Originally, HEA is a tool developed to size restoration projects for the compensation of accidental impacts using ecological services units (Dunford et al., 2004 ; Bruggeman et al., 2005 ; Roach and Wade, 2006 ; Zafonte and Hampton, 2007). Recent publications have highlighted how it is possible to use equivalency tools in order to provide ecosystem valuations in ecological services biophysical units (Dumax et al., 2011; Vaissière et al., 2013). These publications, however, are based on hypothetical case studies. The goal of this paper is to use HEA for real restoration projects carried out in France during the last years in order to discuss the results both from a theoretical and a practical point of view.

The first section of this paper will be dedicated to the presentation of the method and the economic arguments that defend its broader use. We will, in the second section, present the results of its application in four restoration projects in France, based on different institutional frames, and finally discuss these results in perspective of their institutional goals in the third section.

\section{Material and method}

\subsection{Adapting HEA}

In the US, the Habitat Equivalency Analysis (HEA) was developed for the Natural Resource Damage Assessment that evolved from a monetary and welfare valuation to an 
estimation based on the cost of compensatory restoration projects that enhance or improve

natural resource services in a sufficient amount to compensate the public (Burlington, 2002 ; Dunford et al., 2004).

Facing difficulties to obtain valid monetary damage estimates, resource trustees chose to prefer compensatory scaling methods based on ecological services. Service-to-service methods such as HEA, are based on the principle that the values humans place on natural resources are - as an approximate - proportional to the ecological services these resources provide. Damage affects natural resources and associated services and, using a biophysical indicator, one can estimate the loss of ecological services (due to damage) and gain in ecological services (due to the compensatory restoration project).

In this view, HEA is used to determine the appropriate scale of compensatory restoration through a procedure in four steps (Roach and Wade, 2006):

1 - The choice of one or more biophysical metric(s) to be used as indicators of the services provided by ecosystems;

2 - The estimation of the interim ecological service loss from the natural resource injury until it is restored to baseline conditions;

3 - The identification of a range of compensatory restoration projects;

4 - The choice of one or more compensatory restoration projects that provide a present value of service gain equal to the present value of service loss from the natural resource injury.

In the end, HEA values the ecological services produced by a restoration project in the perspective of its institutional objective: the compensation of the loss of ecological services. Compensation can be considered as an institutional objective that will change according to the nature of the impact. In this paper we want to determine if HEA can be used in the context of other institutional objectives. As we aim at valuing ecological service gains associated with restorations that would not take place in the context of compensation, we need to adapt the procedure to calibrate the HEA method to each restoration action.

The rationale of the HEA can be described through Equation (1) (Dunford et al., 2004 ; Zafonte and Hampton, 2007 ; Levrel et al., 2012 ; Vaissière et al., 2013) and is observable on Figure 1. HEA quantifies gains and losses as Discounted Services Acres Years (DSAYs).

$$
V_{I} A_{I} I_{t}(1+r)^{-T_{I}}=V_{R} A_{R} R_{t}(1+r)^{-T_{R}}
$$


$V_{I}$ is the value of the ecological services on the impacted site and $V_{R}$ is the value of the ecological services on the compensatory restoration site.

$A_{I}$ is the surface impacted, the damaged area and $A_{R}$ the surface compensated, the restoration area.

$I_{t}$ is the intensity of damage and $\boldsymbol{R}_{\boldsymbol{t}}$ the intensity of restoration. They vary according to time and this variation is called recovery function on the impact site and maturity function on the restoration site.

$r$ is the discount rate.

$-T_{I}$ is the time scale of the impact and $-T_{R}$ is the time scale of the compensatory restoration.

FIGURE 1 - Changes in ecological services provision on sites of injury and compensation (adapted from Vaissière et al., 2013)

From the initiation of procedure to the calculation of equivalency, HEA relies on some key elements that justify its use for the determination of the compensation of public loss of ecological services. These elements are associated to the calculation of ecological services in Equation (1) and have to be adapted.

First, HEA relies on different hypothesis on the value of ecological service (Dunford et al., 2004 ; Zafonte and Hampton 2007). In the end it assumes that humans derive utility from natural resources in proportion to the ecological services they provide. As so, the services from restoration project designed for compensation, should provide approximately the level of utility expected to reach the objective of compensation of public loss from the injury (Roach and Wade, 2006). Under the same assumptions, the level of utility provided by restoration with another objective could be evaluated in the lights of its expected objectives. This will be the assumption operationalized in our analysis. This assumption is adopted in the expanded HEA.

There is also the possibility for an operator to apply a "compensation ratio" to insert relative preferences for services on impacted sites over services on restoration sites (or the opposite). Equation 1 can be manipulated so as to help operators determine the size of restoration (Equation 2). It is thus possible to apply the ratio of the value of damaged services to the value of restored services $\left(\frac{V_{I}}{V_{R}}\right)$. Ratios can be applied, for example, to give preferences on the type of actions chosen to implement compensatory restoration (Levrel et al., 2012). 


$$
A_{R}=\frac{V_{I}}{V_{R}} \times \frac{A_{I} I_{t}(1+r)^{-T_{I}}}{R_{t}(1+r)^{-T_{R}}}
$$

The second key element is time consideration. In HEA, the application of a discount rate reflects the "social rate of time preference, which reflects society's willingness to shift the 'consumption' of public goods (such as natural resource services) over time" (Dunford et al., 2004, p. 62). As a consequence, it betrays social preference for services produced today rather than tomorrow. In this case, discounting is not applied on the monetary value of ecological services but directly to the biophysical quantity of ecological services. In the case of NRDA procedures, a discount rate of $3 \%$ is generally applied and the time reference is usually based on the year of the impact (NOAA, 1997). The same assumption is used for the adapted HEA. The year of reference will be based on the institutional frame and we will calculate all projects on a 25 -year period.

The third element is the question of the measurement of the level of ecological services through a specific metric. As it is hard and costly to measure all components of an ecosystem, HEA relies on the use of a metric. Generally, the choice of metric is oriented toward an ecological parameter that is representative of the damaged habitats and/or natural resource. This metric is central in the process as it will be used for the determination of losses resulting from damage and the gain associated to compensatory restoration. Thus HEA results will be very sensitive to this choice (Strange et al., 2002, Vaissiere et al., 2013). As we can see on Table 1, various metrics can be found in literature depending on the type of ecosystems and the targeted services or functions. From the observation of the metric, HEA measures ecosystem services as an estimated percentage. Quantification of gains is conducted in perspective of the level of services on the site of injury in its baseline condition. In the adapted HEA, the idea is to adopt a baseline depending on the institution frame in which the assessment makes sense: the good ecological states for the MSFD or the WFD, the no net loss for the Environmental Liability directive and so on.

\begin{tabular}{|c|c|c|c|}
\hline Source & Ecosystem & Targeted function or service & Choice of metric \\
\hline Fonseca et al. & Seagrass & Food source, & Seagrass density (number of \\
\hline
\end{tabular}




\begin{tabular}{|c|c|c|c|}
\hline $\begin{array}{l}(2000) ; \text { Bell } \\
\text { et al. }(2008)\end{array}$ & & $\begin{array}{l}\text { sediments stabilisation and } \\
\text { nutrients cycles }\end{array}$ & roots per unit of surface) \\
\hline \multirow{5}{*}{$\begin{array}{l}\text { Strange et al. } \\
(2002)\end{array}$} & \multirow[t]{5}{*}{ Salt marsh } & Primary production & Biomass \\
\hline & & Habitat & $\begin{array}{lll}\text { Canopy structure } & \text { of } \\
\text { vegetation } & & \end{array}$ \\
\hline & & $\begin{array}{l}\text { Soil development and } \\
\text { biogeochemical cycling }\end{array}$ & Organic matter \\
\hline & & Support of food chain & Infauna \\
\hline & & Secondary production & Shellfish and fish density \\
\hline $\begin{array}{l}\text { Milon and } \\
\text { Dodge (2001) }\end{array}$ & Coral reef & Habitat & Reef surface \\
\hline $\begin{array}{l}\text { Sperduto et al. } \\
(2003)\end{array}$ & Seabirds & Bird population & Abundance \\
\hline $\begin{array}{l}\text { Penn and } \\
\text { Tomasi (2002) }\end{array}$ & Salt marsh & Habitat & $\begin{array}{l}\text { Qualitative observation, } \\
\text { expert judgement and } \\
\text { specific species abundance }\end{array}$ \\
\hline $\begin{array}{l}\text { French McCay } \\
\text { and Rowe } \\
(2003)\end{array}$ & Coastal species & $\begin{array}{l}\text { Habitat participation to food } \\
\text { web }\end{array}$ & $\begin{array}{l}\text { Primary or } \text { secondary } \\
\text { production }\end{array}$ \\
\hline $\begin{array}{l}\text { Cacela et al. } \\
(2005)\end{array}$ & Estuary & Sediments quality & $\begin{array}{l}\text { Toxic element concentration } \\
\text { and effects on biota }\end{array}$ \\
\hline $\begin{array}{l}\text { Bruggeman et } \\
\text { al. } \quad(2005) \text {; } \\
\text { Scribner et al. } \\
(2005)\end{array}$ & Unspecified & $\begin{array}{l}\text { Habitat at metapopulation } \\
\text { scale }\end{array}$ & $\begin{array}{l}\text { Abundance and genetic } \\
\text { variability }\end{array}$ \\
\hline \multirow{2}{*}{$\begin{array}{l}\text { Roach and } \\
\text { Wade (2006) }\end{array}$} & \multirow{2}{*}{$\begin{array}{l}\text { Coastal } \\
\text { wetlands }\end{array}$} & Habitat & \multirow{2}{*}{$\begin{array}{l}\text { Establishment of a model to } \\
\text { estimate impacts of } \\
\text { chemicals }\end{array}$} \\
\hline & & $\begin{array}{l}\text { Damages on wildlife (birds, } \\
\text { mammals and reptiles) }\end{array}$ & \\
\hline
\end{tabular}

Table 1 - Review of possible metrics for HEA and their associated ecosystem and ecological services in the scientific literature

All these elements are of key importance for the application of the method and they are all taken from observations of the damages on natural resources. Table 2 summarizes how the 
expansion of HEA has been carried out in order to be applied to other type of institutional frame (Table 2).

\begin{tabular}{|l|l|l|}
\hline & HEA for compensation & Translation in a broader use \\
\hline Institutional context & $\begin{array}{l}\text { Natural Resource Damage } \\
\text { Assessment }\end{array}$ & $\begin{array}{l}\text { Multiple (Water Framework } \\
\text { Directive, Marine Strategy } \\
\text { Framework actions, } \\
\text { Positive } \\
\text { Compensation...) }\end{array}$ \\
\hline Actor responsible for & $\begin{array}{l}\text { The party responsible of the } \\
\text { impact }\end{array}$ & $\begin{array}{l}\text { Multiple (Private investor, } \\
\text { public actor, NGO...) }\end{array}$ \\
\hline Value of services & $\begin{array}{l}\text { Possible use of ratio to frame } \\
\text { compensation options }\end{array}$ & $\begin{array}{l}\text { Possible use of ratio to frame } \\
\text { restoration options }\end{array}$ \\
\hline Choice of metric & $\begin{array}{l}\text { Depending on the nature of } \\
\text { the impact to compensate }\end{array}$ & $\begin{array}{l}\text { Depending on the nature of } \\
\text { the objective for restoration }\end{array}$ \\
\hline Baseline for measurement & $\begin{array}{l}\text { Initial level of ecological } \\
\text { services on impacted site }\end{array}$ & $\begin{array}{l}\text { Reference level of ecological } \\
\text { services to produce }\end{array}$ \\
\hline Time reference & $\begin{array}{l}\text { Time of the impact } \\
\text { Time of the initiation of the } \\
\text { restoration planning }\end{array}$ \\
\hline
\end{tabular}

\section{Table 2 - Calibration of HEA for the expansion of its use}

In this paper we will apply HEA to the valuation of actions of restoration of ecological services in perspective of their institutional objectives. This work will rely on case studies from four sites in France.

\subsection{Study sites}

Site selection resulted of opportunities resulting from cooperation with a public agency specialized in water and aquatic ecosystem management, the ONEMA (The French National Agency for Water and Aquatic Environments) and Water Agencies. We selected four different case studies in France taking place in different institutional context (Figure 2, Table $3)$.

\begin{tabular}{|l|l|l|l|l|}
\hline & Libellule $^{(B)}$ zone & $\begin{array}{l}\text { Environmental } \\
\text { measures of Port } \\
2000\end{array}$ & Kervigen marsh & Vurpillères \\
stream
\end{tabular}




\begin{tabular}{|c|c|c|c|c|}
\hline $\begin{array}{l}\text { Geographical } \\
\text { context }\end{array}$ & $\begin{array}{l}\text { Saint-Just and } \\
\text { Saint-Nazaire- } \\
\text { de-Pézan } \\
\text { Pop. } 3,068 \\
\text { Languedoc- } \\
\text { Roussillon } \\
\text { Mediterranean }\end{array}$ & $\begin{array}{l}\text { Le Havre } \\
\text { Pop. 300,000 } \\
\text { Upper Normandy } \\
\text { Oceanic }\end{array}$ & $\begin{array}{l}\text { Châteaulin and } \\
\text { Porzay and } \\
\text { surrounding } \\
\text { communities } \\
\text { Pop. 15,000 } \\
\text { Brittany } \\
\text { Oceanic }\end{array}$ & $\begin{array}{l}\text { Labergement- } \\
\text { Sainte-Marie } \\
\text { Pop. 1,000 } \\
\text { Franche- } \\
\text { Comté } \\
\text { Continental }\end{array}$ \\
\hline $\begin{array}{l}\text { Goal of the } \\
\text { restoration } \\
\text { project }\end{array}$ & $\begin{array}{l}\text { Creating a } \\
\text { market for } \\
\text { environmental } \\
\text { mitigation or } \\
\text { natural water } \\
\text { treatment } \\
\text { system }\end{array}$ & $\begin{array}{l}\text { Acceptance of the } \\
\text { ecological impacts } \\
\text { coming from the } \\
\text { extension of the } \\
\text { Port of Le Havre in } \\
\text { the Seine estuaries }\end{array}$ & $\begin{array}{l}\text { Avoiding green } \\
\text { tides }\end{array}$ & $\begin{array}{l}\text { Ecological } \\
\text { restoration of } \\
\text { Vurpillères } \\
\text { stream }\end{array}$ \\
\hline Type of action & $\begin{array}{l}\text { Creation of a } \\
\text { wetland at the } \\
\text { outlet of a } \\
\text { sewage } \\
\text { treatment plant }\end{array}$ & $\begin{array}{l}\text { Home-birds } \\
\text { (shorebirds): } \\
\text { creation of an island } \\
\text { in the sea, creation } \\
\text { of a resting place on } \\
\text { dune } \\
\text {-Production of } \\
\text { mudflats: } \\
\text { creation of a } \\
\text { meander }\end{array}$ & $\begin{array}{l}\text { Producing a } \\
\text { service for } \\
\text { assimilative } \\
\text { decrease of } \\
\text { nitrogen }\end{array}$ & $\begin{array}{l}\text { Restoration of } \\
\text { meanders in } \\
\text { the stream }\end{array}$ \\
\hline Size of projects & $1.5 \mathrm{ha}$ & $\begin{array}{l}45 \text { ha for the resting } \\
\text { place } \\
1.5 \text { ha for the island } \\
300 \text { ha for the } \\
\text { meander }\end{array}$ & $22 \mathrm{ha}$ & $\begin{array}{l}1.1 \mathrm{~km} \text { of } \\
\text { stream }\end{array}$ \\
\hline
\end{tabular}

Table 3 - Presentation of the four case studies 
FIGURE 2 - Location of the four case studies in France

\section{Results}

This part will present the application of HEA to the calculation of the gain of ecological services associated to each of our projects (synthesized in Table 6). As we assert that HEA is a good tool for valuation of a project according to its institutional context and objectives, we will have to synthetically introduce each project.

\subsection{Libellule ${ }^{\circledR}$ Zone}

In 2007, the towns of Saint-Just and Saint-Nazaire-de-Pézan undertook the renovation of their wastewater treatment plant (WWTP). Because of their location in the watershed of a protected Mediterranean lagoon exposed to eutrophication problems (the Or lagoon), partners proposed to create a lagoon system to apply tertiary treatment while securing the rejection of the WWTP. The company in charge offered to support the costs of establishing the lagoon system in exchange for the opportunity to implement the Libellule ${ }^{\circledR}$ zone in place of the original project which merely consisted of a pond planted with reeds. This new system, in addition to the initial objectives, included innovative projects - research program on micropollutants, joint production of a rich biodiversity or credit production for wetland and biodiversity offsets - with the view of using this pilot project to develop a market for implementation of Libellule ${ }^{\circledR}$ zone. It has been operational since 2009. Part of the water leaving the WWTP reaches a succession of wetland habitats - phytoplankton basin, reed marsh, meandering zone, anastomosing array and free zone - complemented by a humid meadow, an alluvial zone, a brush planted with trees and a sand filter (Figure 3).

FIGURE 3 - Map of the Libellule ${ }^{\circledR}$ zone (Image: Biotope)

As the goal of the project manager of the Libellule ${ }^{\circledR}$ zone is the creation of a market for this project, it can be valued in perspective of different objectives corresponding to different institutional contexts that would require implementation of similar projects. On the basis of the data available and the potential targeted markets we can select the elements to calibrate HEA for the calculation of gains of ecological services (Table 4).

If we consider the Libellule ${ }^{\circledR}$ zone in the context of the production of a lagoon system for WWTP, it can be valued in perspective of its objective of tertiary treatment. The reason why 
the project's initiators decided to implement a constructed wetland in this area was the Or lagoon's great sensitivity to eutrophication. Thus we can use information taken from monitoring of the Or lagoon for the application of HEA. Data availability on both sites and discussions with local experts led us to choose dissolved oxygen as a metric of the activity of vegetal species, among the major drivers of purification capacity of the Libellule ${ }^{\circledR}$ zone. Equation 3 shows the calculation of intensity of restoration ( $R$ in Equation 1), we measured the level of dissolved oxygen at the entrance $\left(\boldsymbol{O}_{\boldsymbol{i}}\right)$ and at the exit $\left(\boldsymbol{O}_{\boldsymbol{f}}\right)$ of the Libellule ${ }^{\circledR}$ zone and in the Or lagoon $\left(\boldsymbol{O}_{\boldsymbol{O}}\right)$. Gains valued through HEA are thus measured in perspective of the institutional context in which the project takes place as the enhancement associated to the metrics is measured relatively to the level of the metrics in the Or lagoon. We then calculated the gains using HEA, between the start of the works on WWTP in 2007 and 2032 (on a 25year period length). We valued an amount of 1.26 DSAYS between 2007 (start of the works on the WWTP) and 2032.

$$
\boldsymbol{R}=\frac{\boldsymbol{o}_{f}-\boldsymbol{o}_{i}}{\boldsymbol{O}_{\text {or }}}
$$

We also valued the project in perspective of other objectives such as offset production or security of the WWTP rejects as presented on Table 4. As a result we obtained 9.57 DSAYs and 6.44 DSAYs for the valuation of Libellule ${ }^{\circledR}$ zone in the perspective of offset production for habitat and biodiversity respectively and 6.92 DSAYs in perspective of security of the WWTP rejects.

\begin{tabular}{|l|l|l|l|}
\hline $\begin{array}{l}\text { Objective for } \\
\text { valuation }\end{array}$ & Metrics & Determination of baseline & DSAYs \\
\hline $\begin{array}{l}\text { Tertiary } \\
\text { treatment }\end{array}$ & $\begin{array}{l}\text { Dissolved oxygen : Presence of } \\
\text { dissolved oxygen is an indication of } \\
\text { the chemical activity of vegetal } \\
\text { species in water. }\end{array}$ & $\begin{array}{l}\text { Dissolved oxygen in the } \\
\text { Or lagoon. }\end{array}$ & 1.26 \\
\hline $\begin{array}{l}\text { Offset } \\
\text { production } \\
\text { (Habitats) }\end{array}$ & $\begin{array}{l}\text { Coverage of hydrophytes: Composite } \\
\text { proxy considering surface and deep } \\
\text { hydrophytes. }\end{array}$ & $\begin{array}{l}\text { Coverage of 100\% of } \\
\text { available surface. }\end{array}$ & 9.57 \\
\hline $\begin{array}{l}\text { Security of the } \\
\text { WWTP rejects }\end{array}$ & $\begin{array}{l}\text { Surface of wetland: The total area } \\
\text { occupied by wetland in the entire }^{\text {Libellule }}{ }^{\circledR} \text { zone. }\end{array}$ & $\begin{array}{l}\text { Coverage of } 100 \% \text { of the } \\
\text { entire Libellule }{ }^{\circledR} \text { zone. }\end{array}$ & 6.92 \\
\hline
\end{tabular}




\begin{tabular}{|c|c|c|c|}
\hline $\begin{array}{l}\text { Offset } \\
\text { production } \\
\text { (biodiversity) }\end{array}$ & $\begin{array}{l}\text { Species richness (odonates): } \\
\text { Indicator of the number ofspecies of } \\
\text { dragonflies inventoried on the site }\end{array}$ & $\begin{array}{l}\text { Maximum of species } \\
\text { inventoried on one area in } \\
\text { France }^{\mathrm{a}} \text { from } 1970 \text { to } \\
2006 .\end{array}$ & 6.44 \\
\hline
\end{tabular}

Table 4 - Application of HEA to measure the environmental gains on the Libellule $^{\circledR}$ zone, using different proxys ( ${ }^{\text {a }}$ French society of odonatology, source: INVOD, ESRI)

As shown in Table 4, valuation using HEA is very sensitive to the choice of assumptions for the calculation of gains (particularly for the metric and the reference state). Each of these assumptions can be disputed, thus there is not much sense in considering these results in absolute values. In this view we propose to discuss these values in perspective of the institutional objectives in which these projects take place. DSAYs could then be used as a unit for comparing projects in terms of cost efficiency analysis or enter in multi-criteria analysis.

The implementation of Libellule ${ }^{\circledR}$ zone is conducted to create new markets (e.g. market for mitigation of emerging pollutants such as micropollutants) or to propose a new offer on existing markets (e.g. tertiary treatment of water sewage). These markets are characterized by specific performance criteria and can provide good metrics and reference states for projects, as shown in our example of dissolved oxygen. These markets can also be oriented toward the production of wetlands habitat or biodiversity offsets, for which gains should be valued in perspective of potential impacts on similar ecosystems (for more information on emerging markets for biodiversity see Hough and Robertson [2009], McKenney and Kiesecker [2009] or Coggan et al. [2013]). In this way, HEA can be an interesting tool as it provides a unit for exchange between compensation bankers and project developers.

\subsection{Environmental measures of Port 2000}

The Seine estuary refers to the part of the river that is subject to tidal influence. It is a densely populated region and home to a variety of economic activities. The estuary is characterized by the presence of a high biological diversity (birds, fish, etc.) and included in the Natura 2000 network. It is also protected by the existence of the Nature Reserve of the Seine Estuary. Because of the construction of Port 2000, the Le Havre harbor had to set up two types of environmental measures to offset impacts on local biodiversity: compensatory measures and accompanying measures.

Compensatory measures that focused on the creation of a resting place on dune - a resting area of 45 ha consisting of a basin subject to tidal influence and a large dry area - and an islet resting place - an islet of 5 hectares at low tide which is reduced to 1.5 ha and three smaller 
islets at high tide (Figure 4). As the objective of the islet is to welcome shorebirds at high tides, we retain the surface of 1.5 ha in all calculations. These measures were designed to compensate for the destruction of a disused deposition chamber which had been colonized by seabirds - particularly shorebird species.

Among the accompanying measures we study a rehabilitation project of mudflats. This project involved the creation of an artificial meander to restore 100 ha of mudflats which had undergone a decrease of their surface area at a rate of 20 hectares per year since 1980.

We applied HEA to value these projects in two different ways, first considering the compensatory measures and second considering accompanying measures.

First we focus on the valuation of the two compensatory measures : the repositories for shorebirds. Valuation of projects using HEA is similar to its initial use in the NRDA framework, with the difference that the impact is not accidental and temporary but authorized and permanent. As a result, the objective for valuation of both repository area and islet is the compensation of loss of habitat for shorebirds. According to data availability, we used the global population of shorebirds in the estuary as metric. In 1997, objectives were set for compensatory restoration to compensate loss of population of shorebirds due to port development. We used data produced by Wetland International on observation of the evolution of shorebirds population on the estuary (Aulert et al, 2009) between 1985 and 2007. Works of Port 2000 were finished in 2005, we then assume that after this year, all evolution of the shorebird population at the scale of the estuary will be due to compensatory measures. As we do not have available information after 2007, we have to make assumptions on the maturity curve associated to the intensity of restoration. We assume that because of the last adjustment and good management practice, compensation measures will work and that shorebird population will recover its 1997 level in 2011 with a linear growth from 2007 to 2011. We can then calculate the gains associated to both repositories between 2005 and 2030 using HEA, result is of 0.131 DSAYs.

Considering the accompanying measure, the objective of the project is to restore 100 ha of mudflats by an action on $300 \mathrm{ha}$. Although mudflats didn't appear at the expected place, 60 ha appeared elsewhere, we assume that it is directly linked to the project and use the surface of mudflat as a metric to calculate gains with HEA. According to local observation of Aulert et al. (2009), surface of mudflats appeared is of 45 ha in 2008. We have to make assumptions to reconstitute intensity of restoration in time. Works ended in 2005, as a result we assume that apparition of mudflats started in 2006, letting one year for system stabilization after works. We then assume linear growth between 2006 and 2008 (45 ha) and between 2008 and 2012 
(60 ha) and a stabilization of the system in 2012. Calculation of the ecological gains using HEA gave a result of 9.12 DSAYs for the rehabilitation of mudflats.

As we mentioned in the previous part, these two values make no sense in absolute terms, but we can consider them relatively to each project's objectives. In the case of compensatory measures, we can value the temporal loss of services associated to port development (using the loss side of Equation 1). We measured a total loss of 2.16 DSAYs. According to Equation 2 and the quantity of DSAYs associated to the action of compensation, 16.4 ha of additional compensation would be necessary for the compensation of temporal losses. If we rely on the replacement cost principle, as 46.5 ha cost around 9.9 million EUR, we can value the temporal loss of services associated to shorebirds compensation to an additional 3.3 million EUR.

FIGURE 4 - Aerial view of Port 2000 and the environmental measures accompanying the project (Image: Google Earth - Cnes/Spot Image 2013)

\subsection{Kervigen marsh}

The Kervigen marsh is located in the bay of Douarnenez in Brittany. It is a 22-hectares marsh separated from the sea by a coastal dune. It is crossed by the river Kerharo, whose watershed is known for its intensive agriculture. In the 1960s, adjustments were made to drain the swamp for agriculture. This led to the rectification of the river and the raising of the dune. However, agricultural activity ceased in 1975. In 1990, because of the intense exposure of Douarnenez Bay to green tides, Kervigen marsh became the subject of an experiment to take advantage of its performance in purifying nitrates. The success of this experiment led to the acquisition of land from the local government and the establishment of a rehabilitation program: restoration of the dune and diversion of part of the flow of the river into the marsh with the installation of two systems of sluices for water level management (Figure 5).

FIGURE 5 - Aerial view of Kervigen marsh (Image: Google Earth - DigitalGlobe 2013)

Facing the high purification capacity of the marsh, a broad program of restoration has been included in the nitrate mitigation strategy of the watershed of the Douarneney bay. This program aims at reducing by 50 tons per year the quantity of nitrate in the bay with marsh 
rehabilitation. We will use this objective for the calibration of HEA for valuation of the Kervigen marsh.

Purification performances of the Kervigen marsh varies between 2 and $4 \mathrm{~kg}$ per day per hectare, as the marsh is used 110 days per year (when the water level in river is high enough to allow fish circulation despite deviation in the marsh). Calculation of ecological gains using HEA gave us 0.079 DSAYs and 0.158 DSAYs for performances of 2 and $4 \mathrm{~kg}$ per day per hectare respectively.

The strategy of restoration fixes an objective of reduction of 50 tons of nitrate per year, this can be considered as a deficit of ecological services: if nothing is done $100 \%$ of services will be lost, corresponding to 18.41 DSAYs between 2012 and 2037. Considering the gains associated to the Kervigen marsh rehabilitation we can propose discussion on the different strategies for restoration of marshes (Table 5). Using HEA we can dimension the need of restoration to reach 50 tons of nitrate reduction. We can see that changing the time limit for the objective will change the total surface of project, because of the application of a discount rate that gives preference for services produced in 2012, rather than later.

\begin{tabular}{|l|l|l|}
\hline Strategy for marsh restoration & Surface to restore per year & Total surface to restore \\
\hline Objective in 2012 & $234 \mathrm{ha}$ & $234 \mathrm{ha}$ \\
\hline Objective in 2015 & $64 \mathrm{ha}$ & $254 \mathrm{ha}$ \\
\hline Objective in 2020 & $33 \mathrm{ha}$ & $294 \mathrm{ha}$ \\
\hline
\end{tabular}

Table 5 - Dimensioning restoration plan according to different strategy scenario for a selected performance of $2 \mathrm{~kg} . d a y^{-1} \cdot \mathrm{ha}^{-1}$

\subsection{Vurpillères stream}

The Vurpillères stream is located in the upper Jura mountains, in the Nature Reserve (NR) of Lake Remoray. It is a little over one kilometer long, supplied by a watershed with no anthropogenic activity. It crosses low marshes and peat lands. In the 1960s, with the aim of draining the marshes for agriculture, the stream was channeled. Without releasing usable land, this rectification resulted in a loss of diversity of habitats and species. When the Nature Reserve was established in 1980, public access to the wetlands was completely banned and in 1997 the first management plan enabled the reserve manager to launch the restoration of Vurpillères stream (Figure 6).

Valuation of this restoration project was conducted using HEA. For calibration of the model we used information on monitoring of small invertebrates of the communities : plecoptera, trichoptera and ephemeroptera. Monitoring on the restored stream was conducted 
in 1993, 1998, 2002 and 2007 (Redding, 2009). We chose the species' richness of these communities as a metric for the calculation ; and the number of species at the last observation (2007) as a baseline, assuming that the stream had reached its initial level of services. The application of HEA for the calculation of gains gave 5.79 DSAYs between 1997 date of the project and 2022 .

In the same way, we can calculate the loss associated to the channelization of the stream in 1966 with HEA. We obtain a total of 25.95 DSAYs lost. This underlines that the restoration of ecosystems never takes into account the temporal loss associated with past impacts. In the case of Vurpillères stream, compensation of total losses would have implied a project 4.5 times more important.

FIGURE 6 - Aerial view of the Vurpillères stream (Image Google Earth -GeoEye 2013) 


\begin{tabular}{|c|c|c|c|c|c|}
\hline & \multirow[t]{2}{*}{ Libellule $^{(B)}$ zone } & \multicolumn{2}{|c|}{ Environmental measures of Port 2000} & \multirow[t]{2}{*}{ Kervigen marsh } & \multirow[t]{2}{*}{ Vurpillères stream } \\
\hline & & Mudflats rehabilitation & Repositories & & \\
\hline $\begin{array}{l}\text { Objective for } \\
\text { valuation }\end{array}$ & $\begin{array}{l}\text { Depending on the } \\
\text { targeted market }\end{array}$ & $\begin{array}{l}\text { Creation of } 100 \text { ha of } \\
\text { mudflat }\end{array}$ & $\begin{array}{l}\text { Ecological neutrality of } \\
\text { Port } 2000 \text { on the } \\
\text { shorebirds in the estuary }\end{array}$ & $\begin{array}{l}\text { Reduction of } 50 \mathrm{~kg} \\
\text { nitrate per year through } \\
\text { restoration of marshes }\end{array}$ & $\begin{array}{l}\text { Ecological restoration of } \\
\text { the site to its itinial state }\end{array}$ \\
\hline Metrics & e.g. Dissolved oxygen & Surface of mudflats & $\begin{array}{l}\text { Abundance of shorebirds } \\
\text { in the estuary }\end{array}$ & Absorbed nitrate & Species richness \\
\hline Initial level & $\begin{array}{l}\text { State of metric before } \\
\text { works }\end{array}$ & Null & $\begin{array}{l}\text { Number of shorebirds } \\
\text { before impact }\end{array}$ & $\begin{array}{l}\text { Absorbed nitrate without } \\
\text { the marsh }\end{array}$ & $\begin{array}{l}\text { Number of species } \\
\text { before restoration }\end{array}$ \\
\hline $\begin{array}{l}\text { Intensity of } \\
\text { restoration }\end{array}$ & $\begin{array}{l}\text { Evolution of metrics } \\
\text { during time }\end{array}$ & $\begin{array}{l}\text { Surface of mudflats } \\
\text { observed in } 2008 \text { and } \\
\text { 2012, we assume linear } \\
\text { growth between } \\
\text { observations }\end{array}$ & $\begin{array}{l}\text { Variation of number of } \\
\text { birds from } 2005 \text { and } \\
\text { return to the baseline in } \\
2010 .\end{array}$ & $\begin{array}{l}\text { Purification performance } \\
\text { associated to the latest } \\
\text { measures in } 2008 .\end{array}$ & $\begin{array}{l}\text { Number of observed } \\
\text { species in } 1993,1998, \\
2002 \text { and } 2007, \text { we } \\
\text { assume linear growth } \\
\text { between observations }\end{array}$ \\
\hline $\begin{array}{l}\text { Hyptohsesis } \\
\text { on the final } \\
\text { level }\end{array}$ & $\begin{array}{l}\text { Management plan } \\
\text { maintains level of } \\
\text { service to its } 2011 \text { state. }\end{array}$ & Site is stabilised in 2012. & $\begin{array}{l}\text { Return to the baseline in } \\
2010 .\end{array}$ & $\begin{array}{l}\text { Management plan } \\
\text { maintains performance to } \\
\text { its } 2008 \text { state. }\end{array}$ & $\begin{array}{l}\text { In } 2007, \text { level of service } \\
\text { is back to its initial level. }\end{array}$ \\
\hline $\begin{array}{l}\text { Reference } \\
\text { state }\end{array}$ & $\begin{array}{l}\text { Dissolved oxygen in the } \\
\text { Or lagoon }\end{array}$ & $\begin{array}{l}\text { Objective of mudflat } \\
\text { creation (100 ha) }\end{array}$ & $\begin{array}{l}\text { Number of birds in the } \\
\text { estuary in } 1997\end{array}$ & $\begin{array}{l}\text { Nitrate reduction } \\
\text { objective ( } 50 \text { tons per } \\
\text { year) }\end{array}$ & Species richness in 2007 \\
\hline Reference date & $\begin{array}{l}\text { Beginning of works } \\
\text { (2007) }\end{array}$ & $\begin{array}{l}\text { Beginning of works } \\
\text { (2005) }\end{array}$ & $\begin{array}{l}\text { Beginning of impact } \\
\text { (1997) }\end{array}$ & $\begin{array}{l}\text { Beginning of project } \\
(2010)\end{array}$ & Start of project (1997) \\
\hline DSAYs & 1.26 & 9.12 & 0.131 & 0.079 & 5.79 \\
\hline
\end{tabular}

Table 6 - Synthesis of the application of HEA for valuation of actions of restoration of aquatic ecosystems 


\subsection{Comparative results}

As we mentioned, results of valuation using expanded HEA do not have much sense in absolute value and must be conducted in comparative terms. Table 7 shows the results of a cost-benefit analysis conducted on the basis of the benefits expressed in DSAYs and the cost per hectare of projects. The cost of the project was determined based on the cost of investment and annual costs associated to management and monitoring (when scheduled). Total costs for the project was calculated over the same time period as the one used for DSAYs calculation, i.e. on a 25 year period.

\begin{tabular}{|c|c|c|c|c|c|}
\hline & & Objective & $\begin{array}{l}\text { Cost of project } \\
\text { (EUR/ha) }\end{array}$ & DSAYs & $\begin{array}{l}\text { Cost/Benefit } \\
\text { Ratio }\left(10^{3}\right)\end{array}$ \\
\hline Libellule $^{\circledR}$ zone & & $\begin{array}{l}\text { Market of } \\
\text { lagoon } \\
\text { systems }\end{array}$ & $1,338,000$ & 1.26 & 1062 \\
\hline & & $\begin{array}{l}\text { Offset for } \\
\text { biodiversity }\end{array}$ & $1,338,000$ & 6.44 & 207 \\
\hline $\begin{array}{l}\text { Environmental } \\
\text { measures of }\end{array}$ & $\begin{array}{l}\text { Mudflats } \\
\text { rehabilitation }\end{array}$ & $\begin{array}{l}\text { Production of } \\
\text { mudflats }\end{array}$ & 77,000 & 7.589 & 10 \\
\hline & Repositories & $\begin{array}{l}\text { Compensation } \\
\text { of shorebirds }\end{array}$ & 213,000 & 0.21 & 1014 \\
\hline Kervigen marsh & & $\begin{array}{l}\text { Mitigation of } \\
\text { nitrate }\end{array}$ & 13,600 & 0.0495 & 275 \\
\hline Vurpillères stre & & Restoration & $10,600^{\mathrm{b}}$ & 10.38 & 1 \\
\hline
\end{tabular}

Table 7 - Comparisons of costs and benefits of projects $\left({ }^{b}\right.$ Restoration was applied on 1100 meters of the river, piezometric level was improved on riverbanks on a strip of 10 to 20 meters large on each side of the river. We retain a width of 15 meter on each side to calculate the surface impacted by the restoration project)

\section{Discussion}

HEA can provide a simple tool to clarify the objectives, the means to achieve them and a tool to assess the efficacy of actions to achieve these objectives. It enables us to assess the 
ecological benefits of alternative restoration programs in biophysical units and to compare them in a strong sustainability way.

\subsection{Results}

Comparison of projects using expanded HEA then raised the question of the substitutability of DSAYs. At the level of investment in natural capital, we can compare projects amongst themselves. Such a comparison means to determine the best investment in ecological services regardless of location, ecosystem type or institutional frame. In this way, prioritizing investment at constant budget would imply to choose the project with the lowest cost-benefit ratio. In this way, the more interesting project is the restoration of Vurpillères stream (Table 7).

When we introduce more precise considerations, comparison needs to be conducted with caution. Indeed, as we can see on Table 7, the Libellule zone appears to be the worst project when we consider its benefits in perspective of tertiary treatment of WWTP, whereas it becomes a more interesting investment than bird repositories when we consider its benefits in perspective of offset production for biodiversity. In the same way projects are implemented on specific location, restricting investment to a specific area narrows the set of solution. In this way, the question of the best investment on the Seine estuary would lead to prefer mudflats rehabilitation over bird repositories restoration (Table 7). These issues are related to methodological assumptions that need to be discussed.

\subsection{Methodology}

As mentioned earlier, the HEA methodology relies on key assumptions that need to be discussed in perspective of our proposal for expansion of its use.

First, the value of ecological services is supposed to be constant over time, which might be true for short periods but is more difficult to argue for longer periods as retained by HEA (Zafonte and Hampton, 2007). The question of constant value is also asked regarding the spatial dimension. We have considered this same assumption for our calculation.

Second, HEA applied a discount rate to the ecological services in order to integrate the human time preference for the present. There is an extended literature discussing the problems regarding discount rates and proposing modifications and alternatives (Henderson and Bateman, 1995 ; Weitzmann, 1998 ; Frederick et al., 2002; Young and Hatton McDonald, 2006). As a result, since the time reference is the year of 
impact, projects implemented earlier have a greater value. In the context of our extended approach, this can raise issues. For example in the case of the use of HEA to value production of biodiversity offset, a project implemented before impacts could accumulate enough ecological services to compensate impacts on larger area which seems to be the opposite of the objective of the legislation.

Third, HEA allows the application of a ratio, which can be applied to illustrate preference for some action over another (Levrel et al., 2012) or to weight on the location of compensation regarding the location of the impact. We have not applied any ratio in our calculations, but application of HEA in a decision procedure could consider application of ratio. For example, in the case of the meander, we stated that restoration outcome did not appear at the expected location. A ratio could be applied to underline the inadequacy of the outcomes to the institutional frame and to decrease the value of the project's benefits.

Fourth, the quantity of DSAYs we calculated using HEA is heavily dependent of the choice of metrics (Strange et al., 2002). This is part of the strength of HEA into the NRDA framework, it allows to focus discussion on the choice of the metrics. Adoption of HEA resulted from a will of simplification of the calculation of costs since previously, the complexity and opacity of calculations systems limited implementation of compensation measures.

Fifth, we note that calculation of DSAYs relies on assumptions about the maturity function or the observation of metrics. All assumptions on the value of the metrics explicitly stated in this paper were conducted according to data availability but only rely on authors' arbitration. In its genuine use HEA relies on a more participatory process which helps reduce uncertainty accumulated through assumptions.

All these elements are associated to the fact that the HEA is usually integrated into a specific procedure of decision: the NRDA. This procedure gives a framework for the use of HEA and justifies all the conventions associated to the calibration of the assumptions of the model. Our work only consisted in an exploratory application of the tool. Although results seem interesting, it is now impossible to conclude toward the good integration of HEA into a specific decision process.

\subsection{What place for this new tool?}


The objective of this paper is to discuss the perspective of expanding the use of the HEA to value in biophysical terms the benefits of investment in aquatic ecosystems in perspective of their institutional objectives.

In the end we obtained for each of our study sites a quantity of DSAYs calculated considering the institutional objective of every action. As we mentioned, this quantity of DSAYs has no meaning in absolute terms, it has to be considered in relative terms. In this view valuation with HEA can be used in 3 ways:

-(1) ex ante to size an action in order to produce the exact quantity of ecological services required;

- (2) ex ante to help the arbitration between several projects in order to choose the most adapted project under a specific context;

- (3) ex post to illustrate the benefits of an action under a specific context.

Our proposition is strongly rooted toward the consideration of institutions as they constitute the frame of reference for valuation. Thus we can only discuss the results of valuation using HEA under the objective fixed by the relevant institutions. A restoration project that doesn't meet its objective when implemented for a specific purpose can't be considered as more valuable even if it has a more important monetary value. In this way, the valuation of restoration projects in biophysical terms shows some advantages as it doesn't meet the usual critics addressed to monetary valuation and can thus be a good complement.

Institutional economics considers several obstacles to monetary valuation that can be overcome using biophysical indicators. Vatn and Bromley (1994) described three major obstacles to monetary valuation: cognition problem, incongruity problem and composition problem.

The cognition problem refers to the impossibility for humans to achieve perfect knowledge, which can lead to disregarding some valuable attributes. The use of biophysical indicators can minimize this risk as it carries in itself attributes associated to the functioning of ecosystem.

The incongruity problem relates to the fact that different attributes of natural capital assets can be incompatible with each other in the assessor's mind. For example, increasing filtration capacity can sometimes be at odds with biodiversity conservation when management implies mowing during nesting period (e.g. from Kervigen marsh). Valuing a project in perspective of its institutional objective can help overcome these issues as it helps ranking these attributes. 
Finally, the composition problem is associated to the fact that "the value of individual ecosystem components should not be derived from their perceived utility to humans but rather from their functional contribution to maintaining the integrity of the whole system" (Rees et al., 2007, p 230). This echoes our objective to use biophysical indicator to value an ecosystem toward the achievement of a broader objective.

Our proposition of tool follows the path of scientists from different origins involved in environmental management issues, who promote integrative approaches crossing ecology, economics and institutional analysis. Such as those of the Natural Capital Project founded on the use of multi-criteria analysis and biophysical indicators to provide guidance for investment in natural capital (Goldstein et al., 2008 ; Nelson et al., 2009), the approach of the Restoration of Natural Capital (Aronson et al., 2007) and the Ecological Footprint (Wackernagel et al., 1999) that recognize structural and cognitive barriers to investment in natural capital that can be overcome using valuation in physical terms (Wackernagel and Rees, 1997).

The expansion of HEA as a new ecological services valuation tool is in full agreement with those authors and offers a new tool to improve guidance for investment in natural capital through restoration of aquatic ecosystems. A deeper analysis of the fundamental assumptions of the model can also enlighten concrete dimensions of strong sustainable development: the time dimension, the space dimension, the human power dimension (action for investment), the indicator dimension and the institutional dimension (procedure and governance). If the first four are already the subject of an extended research both generally and especially for HEA, the last dimension still needs some development specifically regarding the procedure associated to the application of the HEA in a concrete decision context that would go over its genuine use.

\section{Acknowledgment}

The authors thank the French National Agency for Water and Aquatic Ecosystems (partnership Onema - Ifremer 2011) for their support in organizing this work. Thanks are also addressed to all the people interviewed for this work and to Antoine Roudier for his assistance with the English version.

\section{References}


Aronson, J., S. Milton, and J. Blignaut (2007), Restoring natural capital: science, business, and practice, Island Press.

Bell, S. S., A. Tewfik, M. O. Hall, and M. S. Fonseca (2008), Evaluation of Seagrass Planting and Monitoring Techniques: Implications for Assessing Restoration Success and Habitat Equivalency, Restoration Ecology, 16(3), 407-416, doi:10.1111/j.1526100X.2007.00308.x.

Bithas, K. (2011), Sustainability and externalities: Is the internalization of externalities a sufficient condition for sustainability?, Ecological Economics, 70(10), 1703-1706, doi:10.1016/j.ecolecon.2011.05.014.

Bruggeman, D. J., M. L. Jones, F. Lupi, and K. T. Scribner (2005), Landscape equivalency analysis: Methodology for estimating spatially explicit biodiversity credits, Environmental Management, 36, 518-534.

Burlington, L. (2002), An Update on Implementation of Natural Resource Damage Assessment and Restoration under OPA, Spill Science \& Technology Bulletin, 7(1-2), 23-29, doi:10.1016/S1353-2561(02)00064-6.

Cacela, D., J. Lipton, D. Beltman, J. Hansen, and R. Wolotira (2005), Associating Ecosystem Service Losses with Indicators of Toxicity in Habitat Equivalency Analysis, Environmental Management, 35(3), 343-351, doi:10.1007/s00267-004-4117-4.

Coggan, A., E. Buitelaar, S. Whitten, and J. Bennett (2013), Factors that influence transaction costs in development offsets: Who bears what and why?, Ecological Economics, 88, 222-231, doi:10.1016/j.ecolecon.2012.12.007.

Costanza, R., and H. E. Daly (1992), Natural Capital and Sustainable Development, Conservation Biology, 6(1), 37-46, doi:10.1046/j.1523-1739.1992.610037.x.

Dumax, N., and A. Rozan (2011), Using an adapted HEP to assess environmental cost, Ecological Economics, 72, 53-59, doi:10.1016/j.ecolecon.2011.09.020.

Dunford, R. W., T. C. Ginn, and W. H. Desvousges (2004), The use of habitat equivalency analysis in natural resource damage assessments, Ecological Economics, 48(1), 49-70, doi:10.1016/j.ecolecon.2003.07.011.

Ekins, P., S. Simon, L. Deutsch, C. Folke, and R. De Groot (2003), A framework for the practical application of the concepts of critical natural capital and strong sustainability, Ecological Economics, 44(2-3), 165-185, doi:10.1016/S0921-8009(02)00272-0.

Fonseca, M., B. E. Julius, and W. Kenworthy (2000), Integrating biology and economics in seagrass restoration: How much is enough and why?, Ecological Engineering, 15(3-4), $227-237$. 
Frederick, S., G. Loewenstein, and T. O'Donoghue (2002), Time Discounting and Time

Preference: A Critical Review, Journal of Economic Literature, 40(2), 351-401, doi:10.1257/002205102320161311.

French McCay, D., and J. Rowe (2003), Habitat restoration as mitigation for lost production at multiple trophic levels, Marine Ecology-Progress Series, 264, 233-247.

Goldstein, J. H., L. Pejchar, and G. C. Daily (2008), Using return-on-investment to guide restoration: a case study from Hawaii, Conservation Letters, 1(5), 236-243, doi:10.1111/j.1755-263X.2008.00031.x.

Heal, G. M. (2000), Nature and the marketplace: capturing the value of ecosystem services, Island Press.

Henderson, N., and I. Bateman (1995), Empirical and public choice evidence for hyperbolic social discount rates and the implications for intergenerational discounting, Environmental and Resource Economics, 5(4), 413-423, doi:10.1007/BF00691577.

Hough, P., and M. Robertson (2008), Mitigation under Section 404 of the Clean Water Act: where it comes from, what it means, Wetlands Ecology and Management, 17(1), 15-33, doi:10.1007/s11273-008-9093-7.

Levrel, H., S. Pioch, and R. Spieler (2012), Compensatory mitigation in marine ecosystems: Which indicators for assessing the "no net loss" goal of ecosystem services and ecological functions?, Marine Policy, 36(6), 1202-1210, doi:10.1016/j.marpol.2012.03.004.

Mäler, K.-G., S. Aniyar, and Å. Jansson (2008), Accounting for ecosystem services as a way to understand the requirements for sustainable development, Proceedings of the National Academy of Sciences, 105(28), 9501 -9506, doi:10.1073/pnas.0708856105.

McKenney, B. A., and J. M. Kiesecker (2009), Policy Development for Biodiversity Offsets: A Review of Offset Frameworks, Environmental Management, 45(1), 165-176, doi:10.1007/s00267-009-9396-3.

Milon, W. J., and R. E. Dodge (2001), Applying habitat equivalency analysis for coral reef damage assessment and restoration, Bulletin of Marine Science, 69(2), 975-988.

Nelson, E. et al. (2009), Modeling multiple ecosystem services, biodiversity conservation, commodity production, and tradeoffs at landscape scales, Frontiers in Ecology and the Environment, 7(1), 4-11, doi:10.1890/080023.

NOAA (1997), Natural Resource Damage Assessment Guidance Document: Scaling Compensatory Restoration Actions (Oil Pollution Act of 1990),

Norgaard, R. B., and C. Bode (1998), Next, the value of God, and other reactions, Ecological Economics, 25(1), 37-39. 
Pearce, D. W., and G. D. Atkinson (1993), Capital theory and the measurement of

sustainable development: an indicator of "weak" sustainability, Ecological Economics, 8(2), 103-108, doi:10.1016/0921-8009(93)90039-9.

Penn, T., and T. Tomasi (2002), Calculating Resource Restoration for an Oil Discharge in Lake Barre, Louisiana, USA, Environmental Management, 29(5), 691-702, doi:10.1007/s00267-001-0059-2.

Ramsey, F. P. (1928), A Mathematical Theory of Saving, The Economic Journal, 38(152), 543-559, doi:10.2307/2224098.

Rees, W. E., J. Farley, E.-T. Vesely, and R. De Groot (2007), Valuing natural capital and the cost and benefits of restoration, in Restoring natural capital, science, business, and practice, J. Aronson, S. J. Mitlon, and J. N. Blignaut.

Roach, B., and W. Wade (2006), Policy evaluation of natural resource injuries using habitat equivalency analysis, Ecological Economics, 58(2), 421-433, doi:10.1016/j.ecolecon.2005.07.019.

Scribner, K. T., J. A. Blanchong, D. J. Bruggeman, B. K. Epperson, C.-Y. Lee, Y.-W. Pan, R. I. Shorey, H. H. Prince, S. R. Winterstein, and D. R. Luukkonen (2005), Geographical Genetics: Conceptual Foundations And Empirical Applications Of Spatial Genetic Data In Wildlife Management, edited by DeYoung and Brennan, Journal of Wildlife Management, 69(4), 1434-1453, doi:10.2193/0022-541X(2005)69[1434:GGCFAE]2.0.CO;2.

Sperduto, M., S. Powers, and M. Donlan (2003), Scaling restoration to achieve quantitative enhancement of loon, seaduck, and other seabird populations, Marine Ecology Progress Series, 264, 221-232, doi:10.3354/meps264221.

Stern, D. I. (1997), Limits to substitution and irreversibility in production and consumption: A neoclassical interpretation of ecological economics, Ecological Economics, 21(3), 197-215, doi:10.1016/S0921-8009(96)00103-6.

Strange, E., H. Galbraith, S. Bickel, D. Mills, D. Beltman, and J. Lipton (2002), Determining ecological equivalence in service-to-service scaling of salt marsh restoration, Environmental Management, 29(2), 290-300.

Vaissière, A.-C., H. Levrel, C. Hily, and D. Le Guyader (2013), Selecting ecological indicators to compare maintenance costs related to the compensation of damaged ecosystem services, Ecological Indicators, 29, 255-269, doi:10.1016/j.ecolind.2013.01.003.

Vatn, A. (2010), An institutional analysis of payments for environmental services, Ecological Economics, 69(6), 1245-1252, doi:10.1016/j.ecolecon.2009.11.018. 
Vatn, A., and D. W. Bromley (1994), Choices without Prices without Apologies, Journal of Environmental Economics and Management, 26(2), 129-148, doi:10.1006/jeem.1994.1008.

Wackernagel, M., and W. E. Rees (1997), Perceptual and structural barriers to investing in natural capital: Economics from an ecological footprint perspective, Ecological Economics, 20(1), 3-24, doi:10.1016/S0921-8009(96)00077-8.

Wackernagel, M., L. Onisto, P. Bello, A. Callejas Linares, I. Susana López Falfán, J. Méndez García, A. Isabel Suárez Guerrero, and M. Guadalupe Suárez Guerrero (1999), National natural capital accounting with the ecological footprint concept, Ecological Economics, 29(3), 375-390, doi:10.1016/S0921-8009(98)90063-5.

Weitzman, M. L. (1998), Why the Far-Distant Future Should Be Discounted at Its Lowest Possible Rate, Journal of Environmental Economics and Management, 36(3), 201-208, doi:10.1006/jeem.1998.1052.

Young, M. D., and D. Hatton MacDonald (2006), How should we discount the future? An environmentak perspective., in Economics and the future: time and discounting in private and public decision making, pp. 121-136, D. J. Pannell and S. G. M. Schilizzi, Cheltenham, UK, and Northampton, MA, USA.

Zafonte, M., and S. Hampton (2007), Exploring welfare implications of resource equivalency analysis in natural resource damage assessments, Ecological Economics, 61(1), 134-145, doi:10.1016/j.ecolecon.2006.02.009. 


\section{Tables}

\begin{tabular}{|c|c|c|c|}
\hline Source & Ecosystem & Targeted function or service & Choice of metric \\
\hline $\begin{array}{l}\text { Fonseca et al. } \\
\text { [2000]; Bell et } \\
\text { al. [2008] }\end{array}$ & Seagrass & $\begin{array}{l}\text { Food source, shelter, } \\
\text { sediments stabilisation and } \\
\text { nutrients cycles }\end{array}$ & $\begin{array}{l}\text { Seagrass density (number of } \\
\text { roots per unit of surface) }\end{array}$ \\
\hline \multirow{5}{*}{$\begin{array}{l}\text { Strange et al. } \\
\text { [2002] }\end{array}$} & \multirow[t]{5}{*}{ Salt marsh } & Primary production & Biomass \\
\hline & & Habitat & $\begin{array}{l}\text { Canopy structure of } \\
\text { vegetation }\end{array}$ \\
\hline & & $\begin{array}{l}\text { Soil development and } \\
\text { biogeochemical cycling }\end{array}$ & Organic matter \\
\hline & & Support of food chain & Infauna \\
\hline & & Secondary production & Shellfish and fish density \\
\hline $\begin{array}{l}\text { Milon and Dodge } \\
\text { [2001] }\end{array}$ & Coral reef & Habitat & Reef surface \\
\hline $\begin{array}{l}\text { Sperduto et al. } \\
\text { [2003] }\end{array}$ & Seabirds & Bird population & Abundance \\
\hline $\begin{array}{l}\text { Penn and Tomasi } \\
\text { [2002] }\end{array}$ & Salt marsh & Habitat & $\begin{array}{l}\text { Qualitative observation, } \\
\text { expert judgement and } \\
\text { specific species abundance }\end{array}$ \\
\hline $\begin{array}{l}\text { French McCay } \\
\text { and Rowe [2003] }\end{array}$ & $\begin{array}{l}\text { Coastal } \\
\text { species }\end{array}$ & $\begin{array}{l}\text { Habitat participation to food } \\
\text { web }\end{array}$ & $\begin{array}{l}\text { Primary or secondary } \\
\text { production }\end{array}$ \\
\hline $\begin{array}{l}\text { Cacela et al. } \\
\text { [2005] }\end{array}$ & Estuary & Sediments quality & $\begin{array}{l}\text { Toxic element concentration } \\
\text { and effects on biota }\end{array}$ \\
\hline $\begin{array}{l}\text { Bruggeman et al. } \\
\text { [2005]; Scribner } \\
\text { et al. }(2005)\end{array}$ & Unspecified & $\begin{array}{l}\text { Habitat at metapopulation } \\
\text { scale }\end{array}$ & $\begin{array}{l}\text { Abundance and genetic } \\
\text { variability }\end{array}$ \\
\hline \multirow{2}{*}{$\begin{array}{l}\text { Roach and Wade } \\
\text { [2006] }\end{array}$} & \multirow{2}{*}{$\begin{array}{l}\text { Coastal } \\
\text { wetlands }\end{array}$} & Habitat & \multirow{2}{*}{$\begin{array}{l}\text { Establishment of a model to } \\
\text { estimate impacts of } \\
\text { chemicals }\end{array}$} \\
\hline & & $\begin{array}{l}\text { Damages on wildlife (birds, } \\
\text { mammals and reptiles) }\end{array}$ & \\
\hline
\end{tabular}

TABLE 1 - Review of possible metrics for HEA and their associated ecosystem and ecological services in the scientific literature 


\begin{tabular}{|l|l|l|}
\hline & HEA for compensation & Translation in a broader use \\
\hline Institutional context & Natural Resource Damage & $\begin{array}{l}\text { Multiple (Water Framework } \\
\text { Directive, Marine Strategy } \\
\text { Framework Directive, } \\
\text { Positive actions, } \\
\text { Compensation...) }\end{array}$ \\
\hline Actor responsible for & $\begin{array}{l}\text { The party responsible of the } \\
\text { impact }\end{array}$ & $\begin{array}{l}\text { Multiple (Private investor, } \\
\text { public actor, NGO...) }\end{array}$ \\
\hline Value of services & $\begin{array}{l}\text { Possible use of ratio to frame } \\
\text { compensation options }\end{array}$ & $\begin{array}{l}\text { Possible use of ratio to frame } \\
\text { restoration options }\end{array}$ \\
\hline Choice of metric & $\begin{array}{l}\text { Depending on the nature of } \\
\text { the impact to compensate }\end{array}$ & $\begin{array}{l}\text { Depending on the nature of } \\
\text { the objective for restoration }\end{array}$ \\
\hline Baseline for measurement & $\begin{array}{l}\text { Initial level of ecological } \\
\text { services on impacted site }\end{array}$ & $\begin{array}{l}\text { Reference level of ecological } \\
\text { services to produce }\end{array}$ \\
\hline Time reference & $\begin{array}{l}\text { Time of the impact } \\
\text { Time of the initiation of the } \\
\text { restoration planning }\end{array}$ \\
\hline
\end{tabular}

TABLE 2 - Calibration of HEA for the expansion of its use 


\begin{tabular}{|c|c|c|c|c|}
\hline & Libellule $^{(\mathbb{R}}$ zone & $\begin{array}{l}\text { Environmental } \\
\text { measures of Port } \\
2000\end{array}$ & Kervigen marsh & $\begin{array}{l}\text { Vurpillères } \\
\text { stream }\end{array}$ \\
\hline $\begin{array}{l}\text { Geographical } \\
\text { context }\end{array}$ & $\begin{array}{l}\text { Saint-Just and } \\
\text { Saint-Nazaire- } \\
\text { de-Pézan } \\
\text { Pop. 3,068 } \\
\text { Languedoc- } \\
\text { Roussillon } \\
\text { Mediterranean }\end{array}$ & $\begin{array}{l}\text { Le Havre } \\
\text { Pop. } 300,000 \\
\text { Upper Normandy } \\
\text { Oceanic }\end{array}$ & $\begin{array}{l}\text { Châteaulin and } \\
\text { Porzay and } \\
\text { surrounding } \\
\text { communities } \\
\text { Pop. 15,000 } \\
\text { Brittany } \\
\text { Oceanic }\end{array}$ & $\begin{array}{l}\text { Labergement- } \\
\text { Sainte-Marie } \\
\text { Pop. 1,000 } \\
\text { Franche- } \\
\text { Comté } \\
\text { Continental }\end{array}$ \\
\hline $\begin{array}{l}\text { Goal of the } \\
\text { restoration } \\
\text { project }\end{array}$ & $\begin{array}{l}\text { Creating a } \\
\text { market for } \\
\text { environmental } \\
\text { mitigation or } \\
\text { natural water } \\
\text { treatment } \\
\text { system }\end{array}$ & $\begin{array}{l}\text { Acceptance of the } \\
\text { ecological impacts } \\
\text { coming from the } \\
\text { extension of the } \\
\text { Port of Le Havre in } \\
\text { the Seine estuaries }\end{array}$ & $\begin{array}{l}\text { Avoiding green } \\
\text { tides }\end{array}$ & $\begin{array}{l}\text { Ecological } \\
\text { restoration of } \\
\text { Vurpillères } \\
\text { stream }\end{array}$ \\
\hline Type of action & $\begin{array}{l}\text { Creation of a } \\
\text { wetland at the } \\
\text { outlet of a } \\
\text { sewage } \\
\text { treatment plant }\end{array}$ & $\begin{array}{l}\text { Home-birds } \\
\text { (shorebirds): } \\
\text { creation of an island } \\
\text { in the sea, creation } \\
\text { of a resting place on } \\
\text { dune } \\
\text {-Production of } \\
\text { mudflats: } \\
\text { creation of a } \\
\text { meander }\end{array}$ & $\begin{array}{l}\text { Producing a } \\
\text { service for } \\
\text { assimilative } \\
\text { decrease of } \\
\text { nitrogen }\end{array}$ & $\begin{array}{l}\text { Restoration of } \\
\text { meanders in } \\
\text { the stream }\end{array}$ \\
\hline Size of projects & $1.5 \mathrm{ha}$ & $\begin{array}{l}45 \text { ha for the resting } \\
\text { place } \\
1.5 \text { ha for the island } \\
300 \text { ha for the } \\
\text { meander }\end{array}$ & $22 \mathrm{ha}$ & $\begin{array}{l}1.1 \mathrm{~km} \text { of } \\
\text { stream }\end{array}$ \\
\hline
\end{tabular}

TABLE 3 - Presentation of the four case studies 


\begin{tabular}{|l|l|l|l|}
\hline $\begin{array}{l}\text { Objective for } \\
\text { valuation }\end{array}$ & Metrics & Determination of baseline & DSAYs \\
\hline Tertiary & $\begin{array}{l}\text { Dissolved oxygen : Presence of } \\
\text { dissolved oxygen is an indication of } \\
\text { the chemical activity of vegetal } \\
\text { species in water. }\end{array}$ & $\begin{array}{l}\text { Dissolved oxygen in the } \\
\text { Or lagoon. }\end{array}$ & 1.26 \\
\hline $\begin{array}{l}\text { Offset } \\
\text { production } \\
\text { (Habitats) }\end{array}$ & $\begin{array}{l}\text { Coverage of hydrophytes: Composite } \\
\text { proxy considering surface and deep } \\
\text { hydrophytes. }\end{array}$ & $\begin{array}{l}\text { Coverage of } 100 \% \text { of } \\
\text { available surface. }\end{array}$ & 9.57 \\
\hline $\begin{array}{l}\text { Security of the } \\
\text { WWTP rejects }\end{array}$ & $\begin{array}{l}\text { Surface of wetland: The total area } \\
\text { occupied by wetland in the entire } \\
\text { Libellule }{ }^{\circledR} \text { zone. }\end{array}$ & $\begin{array}{l}\text { Coverage of 100\% of the } \\
\text { entire Libellule }{ }^{\circledR} \text { zone. }\end{array}$ & 6.92 \\
\hline $\begin{array}{l}\text { Offset } \\
\text { production } \\
\text { (biodiversity) }\end{array}$ & $\begin{array}{l}\text { Species richness (odonates) : } \\
\text { Indicator of the number of species of } \\
\text { dragonflies inventoried on the site }\end{array}$ & $\begin{array}{l}\text { Maximum of species } \\
\text { inventoried on one area in } \\
\text { France }{ }^{\text {a }} \text { from 1970 to } \\
\text { 2006. }\end{array}$ & 6.44 \\
\hline
\end{tabular}

TABLE 4 - Application of HEA to measure ecological services according to different metrics

( ${ }^{\mathrm{a}}$ French society of odonatology, source: INVOD, ESRI)

\begin{tabular}{|l|l|l|}
\hline Strategy for marsh restoration & Surface to restore per year & Total surface to restore \\
\hline Objective in 2012 & 234 ha & 234 ha \\
\hline Objective in 2015 & 64 ha & 254 ha \\
\hline Objective in 2020 & 33 ha & 294 ha \\
\hline
\end{tabular}

TABLE 5 - Dimensioning restoration plan according to different strategy scenario for a selected performance of $2 \mathrm{~kg} \cdot \mathrm{day}^{-1} \cdot \mathrm{ha}^{-1}$ 


\begin{tabular}{|c|c|c|c|c|c|}
\hline & Libellule $^{(B)}$ zone & Environmental measures & of Port 2000 & Kervigen marsh & Vurpillères stream \\
\hline & & Mudflats rehabilitation & Repositories & & \\
\hline $\begin{array}{l}\text { Objectif de } \\
\text { valorisation }\end{array}$ & $\begin{array}{l}\text { Depending on the } \\
\text { targeted market }\end{array}$ & $\begin{array}{l}\text { Creation of } 100 \text { ha of } \\
\text { mudflat }\end{array}$ & $\begin{array}{l}\text { Ecological neutrality of } \\
\text { Port } 2000 \text { on the } \\
\text { shorebirds in the estuary }\end{array}$ & $\begin{array}{l}\text { Reduction of } 50 \mathrm{~kg} \\
\text { nitrate per year through } \\
\text { restoration of marshes }\end{array}$ & $\begin{array}{l}\text { Ecological restoration } \\
\text { of the site to its initial } \\
\text { state }\end{array}$ \\
\hline Metrics & e.g. Dissolved oxygen & Surface of mudflats & $\begin{array}{l}\text { Abundance of shorebirds } \\
\text { in the estuary }\end{array}$ & Absorbed nitrate & Species richness \\
\hline $\begin{array}{l}\text { Intensity of } \\
\text { restoration }\end{array}$ & $\begin{array}{l}\text { Evolution of metrics } \\
\text { during time }\end{array}$ & $\begin{array}{l}\text { Observations in } 2008 \\
\text { and } 2012 \text {, we assume } \\
\text { linear growth between } \\
\text { observations }\end{array}$ & $\begin{array}{l}\text { Variation of number of } \\
\text { birds from } 2005 \text { and } \\
\text { return to the baseline in } \\
2010 .\end{array}$ & $\begin{array}{l}\text { Purification performance } \\
\text { associated to the latest } \\
\text { measures in } 2008 \text {. }\end{array}$ & $\begin{array}{l}\text { Observations in 1993, } \\
\text { 1998, } 2002 \text { and 2007, } \\
\text { we assume linear } \\
\text { growth between } \\
\text { observations }\end{array}$ \\
\hline $\begin{array}{l}\text { Hypothesis } \\
\text { on the final } \\
\text { level }\end{array}$ & $\begin{array}{l}\text { Management plan } \\
\text { maintains level of } \\
\text { service to its } 2011 \text { state. }\end{array}$ & $\begin{array}{l}\text { Site is stabilised in } \\
\text { 2012. }\end{array}$ & $\begin{array}{l}\text { Return to the baseline in } \\
2010 .\end{array}$ & $\begin{array}{l}\text { Management plan } \\
\text { maintains performance to } \\
\text { its } 2008 \text { state. }\end{array}$ & $\begin{array}{l}\text { In 2007, level of } \\
\text { service is back to its } \\
\text { initial level. }\end{array}$ \\
\hline $\begin{array}{l}\text { Référence } \\
\text { state }\end{array}$ & Or lagoon & $\begin{array}{l}\text { Project objective (100 } \\
\text { ha) }\end{array}$ & Metric in 1997 & $\begin{array}{ll}\text { Policy objective } & (50 \\
\left.\text { t.year }^{-1}\right) & \end{array}$ & $\begin{array}{l}\text { Species richness in } \\
2007\end{array}$ \\
\hline $\begin{array}{l}\text { Reference } \\
\text { date }\end{array}$ & $\begin{array}{l}\text { Beginning of works } \\
(2007)\end{array}$ & $\begin{array}{l}\text { Beginning of works } \\
(2005)\end{array}$ & $\begin{array}{l}\text { Beginning of impact } \\
\text { (1997) }\end{array}$ & $\begin{array}{l}\text { Beginning of project } \\
(2010)\end{array}$ & Start of project (1997) \\
\hline DSAYs & 1.26 & 9.12 & 0.131 & 0.079 & 5.79 \\
\hline
\end{tabular}

TABLE 6 - Synthesis of the application of HEA for valuation of actions of restoration of aquatic ecosystems 


\begin{tabular}{|c|c|c|c|c|c|}
\hline & & Objective & $\begin{array}{l}\text { Cost of project } \\
(\mathrm{EUR} / \mathrm{ha})\end{array}$ & DSAYs & $\begin{array}{l}\text { Cost/Benefit } \\
\text { Ratio }\left(10^{3}\right)\end{array}$ \\
\hline \multirow{2}{*}{\multicolumn{2}{|c|}{ Libellule $^{(B)}$ zone }} & $\begin{array}{ll}\text { Market of } \\
\text { lagoon } \\
\text { systems }\end{array}$ & $1,338,000$ & 1.26 & 1062 \\
\hline & & $\begin{array}{l}\text { Offset for } \\
\text { biodiversity }\end{array}$ & $1,338,000$ & 6.44 & 207 \\
\hline \multirow{2}{*}{$\begin{array}{l}\text { Environmental } \\
\text { measures of } \\
\text { Port } 2000\end{array}$} & $\begin{array}{l}\text { Mudflats } \\
\text { rehabilitation }\end{array}$ & $\begin{array}{l}\text { Production of } \\
\text { mudflats }\end{array}$ & 77,000 & 7.589 & 10 \\
\hline & Repositories & $\begin{array}{l}\text { Compensation } \\
\text { of shorebirds }\end{array}$ & 213,000 & 0.21 & 1014 \\
\hline \multicolumn{2}{|l|}{ Kervigen marsh } & $\begin{array}{l}\text { Mitigation of } \\
\text { nitrate }\end{array}$ & 13,600 & 0.0495 & 275 \\
\hline \multicolumn{2}{|c|}{ Vurpillères stream } & Restoration & $10,600^{b}$ & 10.38 & 1 \\
\hline
\end{tabular}

TABLE 7 - Comparison of costs and benefits of projects

$\left({ }^{b}\right.$ Restoration was applied on 1100 meters of the river, piezometric level was improved on riverbanks on a strip of 10 to 20 meters large on each side of the river. We retain a width of 15 meter on each side to calculate the surface impacted by the restoration project) 


\section{Figure}

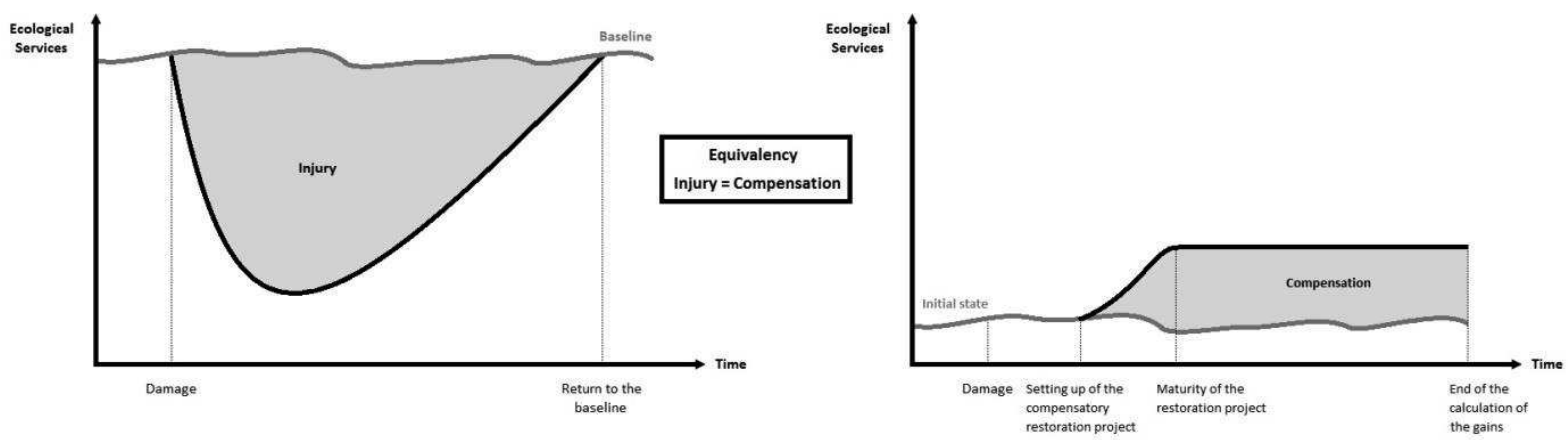

FIGURE 1 - Changes in ecological services provision on sites of injury and compensation (adapted from Vaissière et al., 2013)

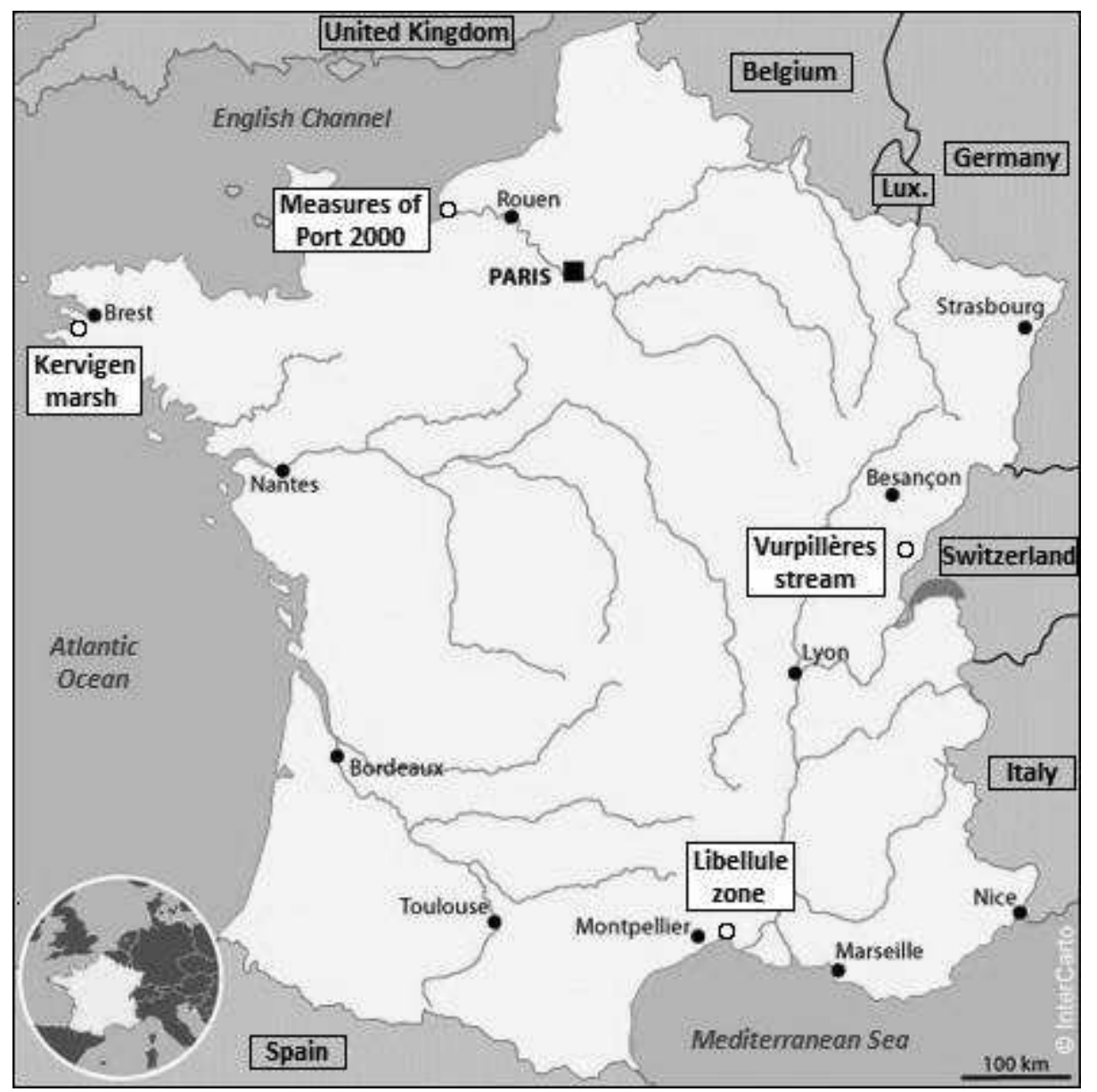

FIGURE 2 - Location of the four case studies in France 


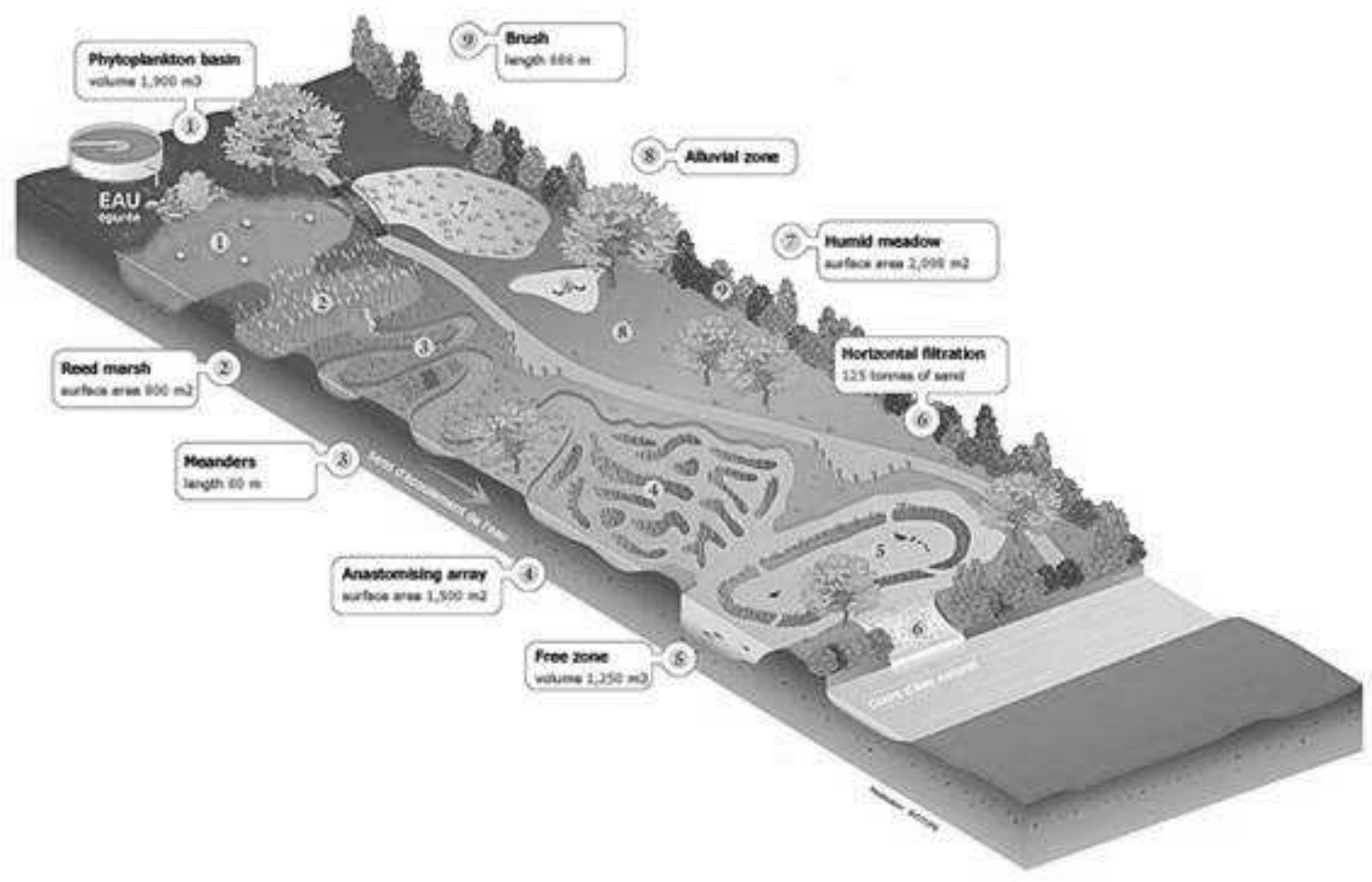

FIGURE 3 - Map of the Libellule zone (Image: Biotope)

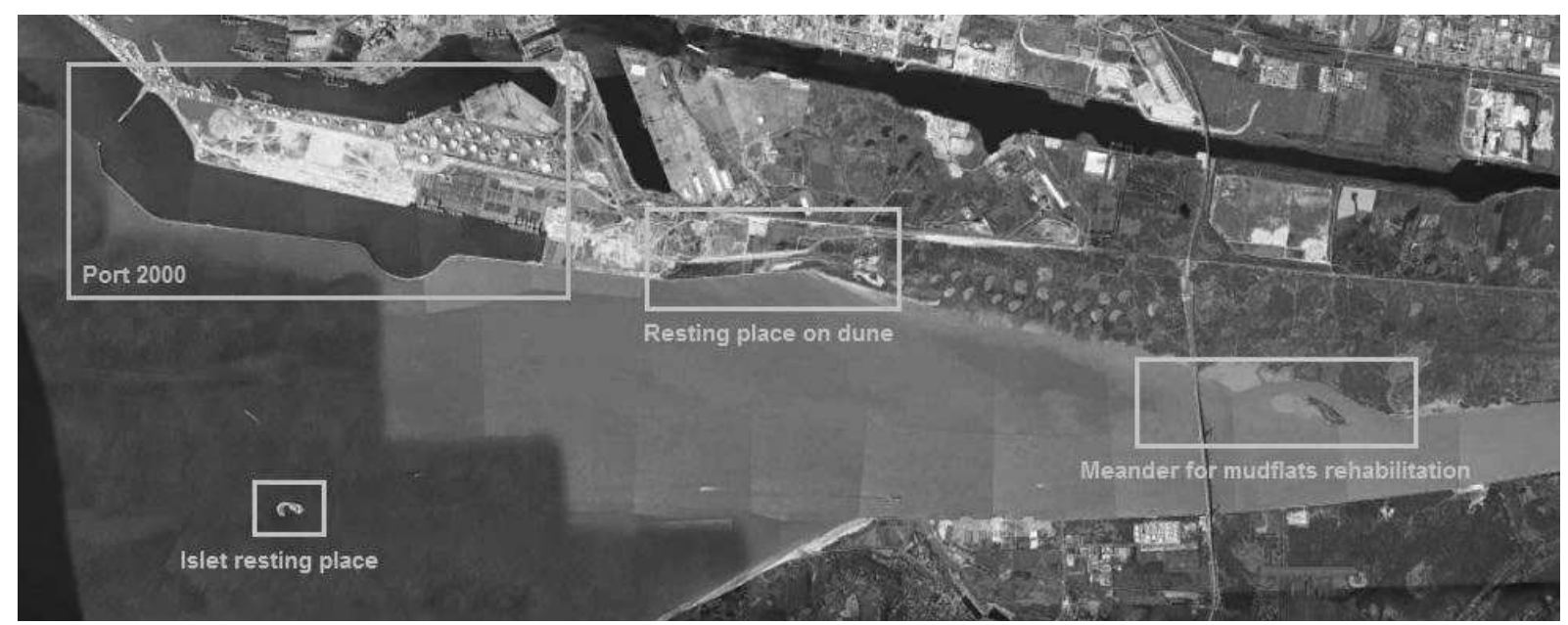

FIGURE 4 - Aerial view of Port 2000 and the environmental measures accompanying the project (Image: Google Earth - Cnes/Spot Image 2013) 


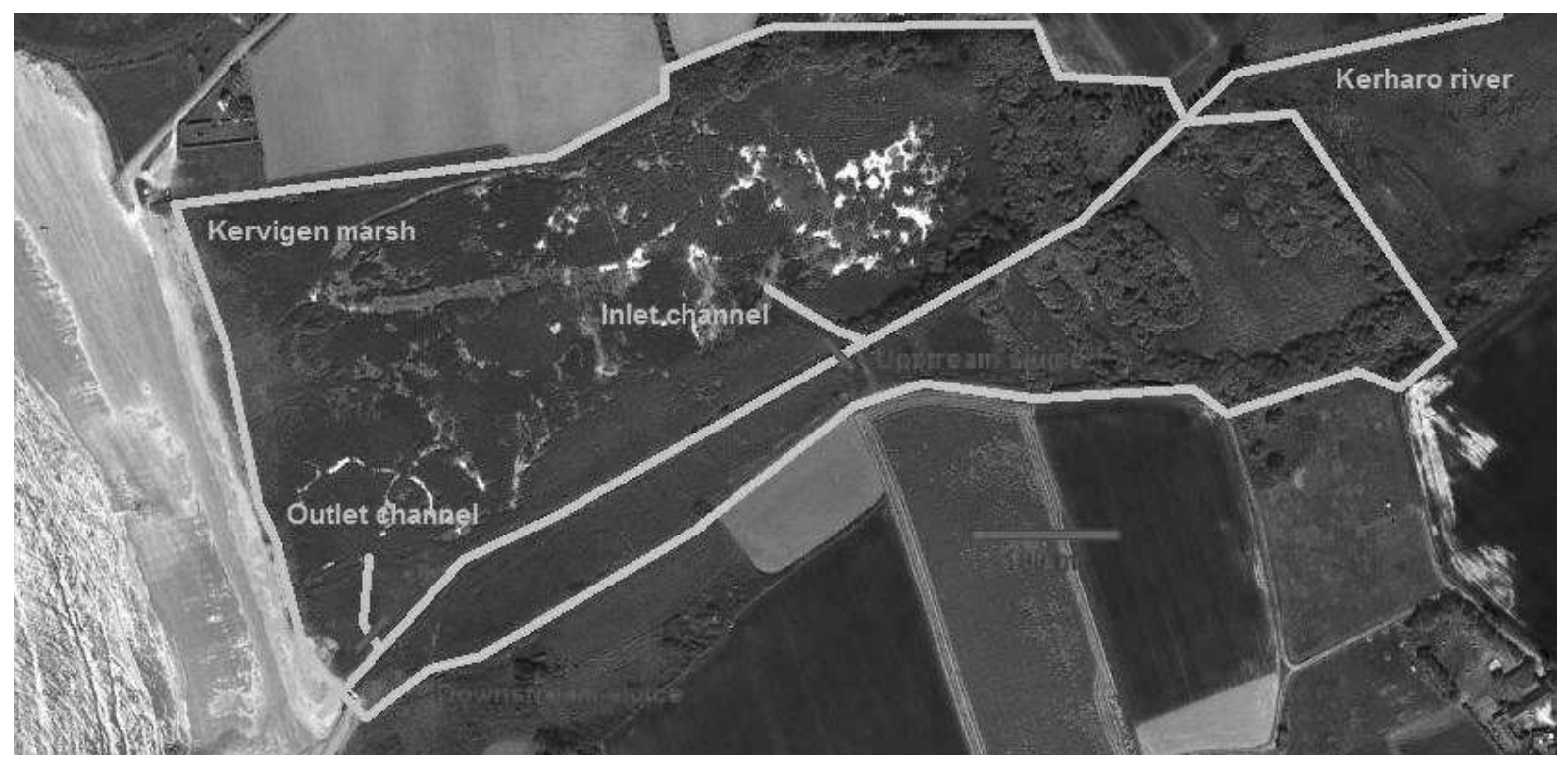

FIGURE 5 - Aerial view of Kervigen marsh (Image: Google Earth - DigitalGlobe 2013)

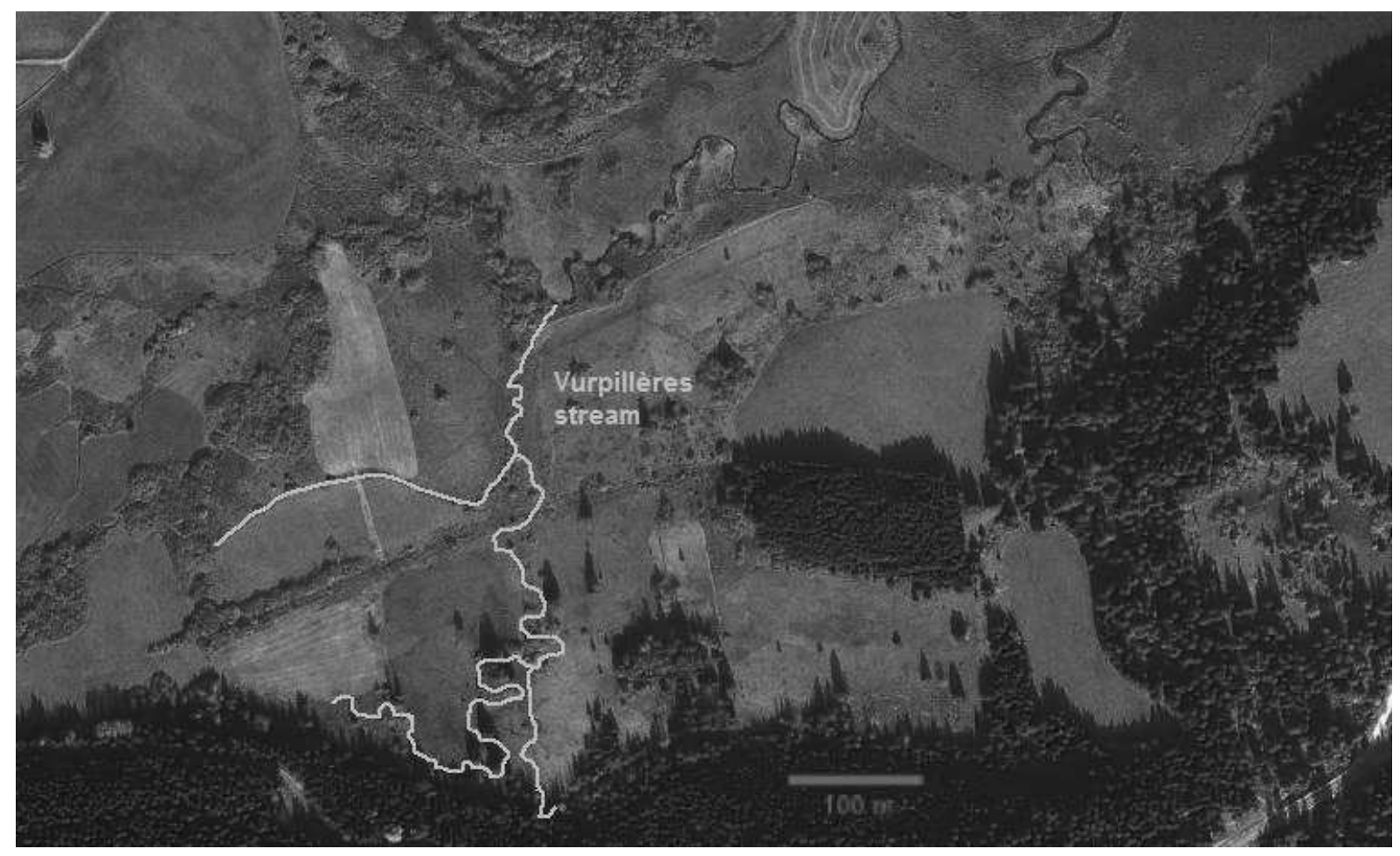

FIGURE 6 - Aerial view of the Vurpillères stream (Image Google Earth -GeoEye 2013) 


\section{Supplementary material}

This document provides the details of the calculation realized in the article. For each site we will present the calculation of DSAYs associated to benefits of the project and the calculation of costs of projects.

Calculation of DSAYs associated to restoration project will be conducted according to formula (1). Calculation will be explained so as to underline what are the elements necessary for calibration of the model and for calculation.

$$
\mathbf{G}=V_{R} \times \sum_{\mathrm{t}=\mathrm{i}}^{\mathrm{t}=\mathrm{n}}\left[R_{t}(1+r)^{-t}\right]
$$

$V_{R}$ designate the value of the services produced on the restoration site, we don't apply any modifier for the value of services $\left(V_{R}=1\right)$.

$\boldsymbol{R}_{t}$ is the intensity of restoration at year $\mathrm{t}$, it designates the level of services gained through the project, usually it is calculated as the value of the gains associated to the state of the metrics at year $t$ (the difference between initial and final state) divided by the value of the metric on the reference site. The variation of $\boldsymbol{R}_{t}$ during time is called maturity curve. The difference between initial and final state is selected to catch the effect of the restoration project, the difference between the situation without restoration action and the situation with the action.

$r$ is the discount rate, we apply a value of $3 \%$.

Calculation is done for each year between the initiation of the project (i) and a selected horizon (n). In our calculations, the initiation date correspond to the year of the initiation of the project, for coherence, all calculation will be conducted on a 25 years period.

For all examples, information needed to the calculation will be summarized in tables, the first one will presents the assumptions needed for the calibration of the model to a specific objective, the second one will present the maturity function (the rate of intensity of restoration during time) and the third one will present the matrix of calculation of DSAYs.

\section{Libellule ${ }^{\circledR}$ Zone}

\subsection{Tertiary treatment measured through dissolved oxygen}

\begin{tabular}{|l|l|}
\hline Project & Libellule Zone \\
\hline Objective & Tertiary treatment \\
\hline Metric & Dissolved oxygen \\
\hline Reference state & Level of metric in the Or lagoon \\
\hline
\end{tabular}




\begin{tabular}{|l|l|}
\hline Maturity curve & $\begin{array}{l}\text { The project is initiated in 2007, production of services starts in } 2010 \text { and reaches } \\
\text { its maximum level of services in } 2011 \text { and we have data on the metric for } 2010 \text { and } \\
2011 \text { (Table 1.1.2) }\end{array}$ \\
\hline Initiation year & 2007 \\
\hline Final year & 2032 \\
\hline
\end{tabular}

Table 1.1.1 - Assumptions and information needed for calculation of DSAYs to value the benefits of Libellule zone toward its objective of tertiary treatment

\begin{tabular}{|l|l|l|l|l|}
\hline & $\begin{array}{l}\text { Dissolved oxygen at } \\
\text { the entrance of } \\
\text { Libellule zone }\end{array}$ & $\begin{array}{l}\text { Dissolved oxygen } \\
\text { at the exit of } \\
\text { Libellule zone }\end{array}$ & $\begin{array}{l}\text { Dissolved oxygen } \\
\text { in the Or Lagoon }\end{array}$ & $\begin{array}{l}\text { Value of the } \\
\text { metric }\end{array}$ \\
\hline $2007-2009$ & No data & $\begin{array}{l}\text { Supposedly } \\
\text { unchanged }\end{array}$ & No data & 0 \\
\hline 2010 & 9,2 & 9,9 & 10 & 0,074 \\
\hline 2011 & 9,1 & 9,9 & 9,9 & 0,079 \\
\hline
\end{tabular}

Table 1.1.2 - Maturity curve of the restoration project, values of the metric of dissolved oxygen values during time

We can then calculate the benefit associated to the objective of tertiary treatment using the dissolved oxygen as proxy of the level of ecological services (Table 1.1.3).

\begin{tabular}{|c|c|c|c|c|c|}
\hline & \multicolumn{2}{|c|}{$\begin{array}{c}\text { Level of services gains associated } \\
\text { to the project }\end{array}$} & $\begin{array}{l}\text { Mean gain of } \\
\text { services }\end{array}$ & Discount factor & Unitary gains \\
\hline & \multicolumn{2}{|c|}{$\begin{array}{c}\Delta \text { (Input/Output) Dissolved oxygen } \\
\text { / Dissolved oxygen in the Or } \\
\text { lagoon }\end{array}$} & \multirow[t]{2}{*}{$\begin{array}{c}(3)=(1)+(2) / \\
2\end{array}$} & \multirow[t]{2}{*}{$(4)=(1+r)^{(2007-t)}$} & \multirow[t]{2}{*}{$(5)=(3) \times(4)$} \\
\hline & Initial (1) & Final (2) & & & \\
\hline 2007 & 0,000 & 0,000 & 0,000 & 1,00 & 0,000 \\
\hline 2008 & 0,000 & 0,000 & 0,000 & 0,97 & 0,000 \\
\hline 2009 & 0,000 & 0,074 & 0,037 & 0,94 & 0,035 \\
\hline 2010 & 0,074 & 0,079 & 0,077 & 0,92 & 0,070 \\
\hline 2011 & 0,079 & 0,079 & 0,079 & 0,89 & 0,071 \\
\hline 2012 & 0,079 & 0,079 & 0,079 & 0,86 & 0,069 \\
\hline 2013 & 0,079 & 0,079 & 0,079 & 0,84 & 0,067 \\
\hline 2014 & 0,079 & 0,079 & 0,079 & 0,81 & 0,065 \\
\hline 2015 & 0,079 & 0,079 & 0,079 & 0,79 & 0,063 \\
\hline 2016 & 0,079 & 0,079 & 0,079 & 0,77 & 0,061 \\
\hline 2017 & 0,079 & 0,079 & 0,079 & 0,74 & 0,059 \\
\hline 2018 & 0,079 & 0,079 & 0,079 & 0,72 & 0,057 \\
\hline 2019 & 0,079 & 0,079 & 0,079 & 0,70 & 0,056 \\
\hline 2020 & 0,079 & 0,079 & 0,079 & 0,68 & 0,054 \\
\hline 2021 & 0,079 & 0,079 & 0,079 & 0,66 & 0,053 \\
\hline 2022 & 0,079 & 0,079 & 0,079 & 0,64 & 0,051 \\
\hline 2023 & 0,079 & 0,079 & 0,079 & 0,62 & 0,050 \\
\hline 2024 & 0,079 & 0,079 & 0,079 & 0,61 & 0,048 \\
\hline
\end{tabular}




\begin{tabular}{|r|r|r|r|r|r|}
\hline 2025 & 0,079 & 0,079 & 0,079 & 0,59 & 0,047 \\
\hline 2026 & 0,079 & 0,079 & 0,079 & 0,57 & 0,045 \\
\hline 2027 & 0,079 & 0,079 & 0,079 & 0,55 & 0,044 \\
\hline 2028 & 0,079 & 0,079 & 0,079 & 0,54 & 0,043 \\
\hline 2029 & 0,079 & 0,079 & 0,079 & 0,52 & 0,041 \\
\hline 2030 & 0,079 & 0,079 & 0,079 & 0,51 & 0,040 \\
\hline 2031 & 0,079 & 0,079 & 0,079 & 0,49 & 0,039 \\
\hline 2032 & 0,079 & 0,079 & 0,079 & 0,48 & 0,038 \\
\hline
\end{tabular}

Table 1.1.3 - Calculation of the DSAYs to value the benefits of Libellule zone toward its objective of tertiary treatment

\subsection{Offset production for habitat measured through vegetation} coverage

\begin{tabular}{|l|l|}
\hline Project & Libellule Zone \\
\hline Objective & Offset production (Habitat) \\
\hline Metric & Coverage of hydrophytes \\
\hline Reference state & Hypothetical maximum coverage of 100\% \\
\hline Maturity curve & $\begin{array}{l}\text { The project is initiated in 2007, production of services starts in } 2010 \text { and reaches } \\
\text { its maximum level of services in } 2011 \text { and we have data on the metric for } 2010 \text { and } \\
2011 \text { (Table 1.2.2) }\end{array}$ \\
\hline Initiation year & 2007 \\
\hline Final year & 2032 \\
\hline
\end{tabular}

Table 1.2.1 - Assumptions and information needed for calculation of DSAYs to value the benefits of Libellule zone toward its objective of offset production for habitat

\begin{tabular}{|l|l|l|l|l|}
\hline & $\begin{array}{l}\text { Coverage of } \\
\text { hydrophytes } \\
\text { without Libellule } \\
\text { zone }\end{array}$ & $\begin{array}{l}\text { Coverage of } \\
\text { hydrophytes in } \\
\text { the Libellule zone }\end{array}$ & $\begin{array}{l}\text { Hypothetical } \\
\text { maximum of } \\
100 \% \text { coverage }\end{array}$ & Value of the \\
\hline $2007-2009$ & 0 & 0 & 1 & 0 \\
\hline 2010 & 0 & 0,41 & 1 & 0,41 \\
\hline 2011 & 0 & 0,61 & 1 & 0,61 \\
\hline $2012-2032$ & 0 & 0,61 & 1 & 0,61 \\
\hline
\end{tabular}

Table 1.2.2 - Maturity curve of the restoration project, values of the metric of hydrophytes coverage values during time 


\begin{tabular}{|c|c|c|c|c|c|}
\hline & \multicolumn{2}{|c|}{ \% Coverage of hydrophytes / 100} & \multirow[t]{2}{*}{$(3)=(1)+(2) / /$} & \multirow[t]{2}{*}{$(4)=(1+r)^{(2007-t)}$} & \multirow[t]{2}{*}{$(5)=(3) \times(4)$} \\
\hline & Initial (1) & Final (2) & & & \\
\hline 2007 & 0,00 & 0,00 & 0,00 & 1,00 & 0,00 \\
\hline 2008 & 0,00 & 0,00 & 0,00 & 0,97 & 0,00 \\
\hline 2009 & 0,00 & 0,41 & 0,21 & 0,94 & 0,19 \\
\hline 2010 & 0,41 & 0,61 & 0,51 & 0,92 & 0,47 \\
\hline 2011 & 0,61 & 0,61 & 0,61 & 0,89 & 0,54 \\
\hline 2012 & 0,61 & 0,61 & 0,61 & 0,86 & 0,53 \\
\hline 2013 & 0,61 & 0,61 & 0,61 & 0,84 & 0,51 \\
\hline 2014 & 0,61 & 0,61 & 0,61 & 0,81 & 0,50 \\
\hline 2015 & 0,61 & 0,61 & 0,61 & 0,79 & 0,48 \\
\hline 2016 & 0,61 & 0,61 & 0,61 & 0,77 & 0,47 \\
\hline 2017 & 0,61 & 0,61 & 0,61 & 0,74 & 0,45 \\
\hline 2018 & 0,61 & 0,61 & 0,61 & 0,72 & 0,44 \\
\hline 2019 & 0,61 & 0,61 & 0,61 & 0,70 & 0,43 \\
\hline 2020 & 0,61 & 0,61 & 0,61 & 0,68 & 0,42 \\
\hline 2021 & 0,61 & 0,61 & 0,61 & 0,66 & 0,40 \\
\hline 2022 & 0,61 & 0,61 & 0,61 & 0,64 & 0,39 \\
\hline 2023 & 0,61 & 0,61 & 0,61 & 0,62 & 0,38 \\
\hline 2024 & 0,61 & 0,61 & 0,61 & 0,61 & 0,37 \\
\hline 2025 & 0,61 & 0,61 & 0,61 & 0,59 & 0,36 \\
\hline 2026 & 0,61 & 0,61 & 0,61 & 0,57 & 0,35 \\
\hline 2027 & 0,61 & 0,61 & 0,61 & 0,55 & 0,34 \\
\hline 2028 & 0,61 & 0,61 & 0,61 & 0,54 & 0,33 \\
\hline 2029 & 0,61 & 0,61 & 0,61 & 0,52 & 0,32 \\
\hline 2030 & 0,61 & 0,61 & 0,61 & 0,51 & 0,31 \\
\hline 2031 & 0,61 & 0,61 & 0,61 & 0,49 & 0,30 \\
\hline & & & & DSAYS & 9,57 \\
\hline
\end{tabular}

Table 1.2.3 - Calculation of the DSAYs to value the benefits of Libellule zone toward its objective of offset production for habitat

\subsection{Security of the wastewater treatment plant's rejects through the surface of wetland}

\begin{tabular}{|l|l|}
\hline Project & Libellule Zone \\
\hline Objective & Security of the wastewater treatment plant's rejects (WWTP) \\
\hline Metric & Surface of wetland in the total Libellule zone \\
\hline Reference state & Hypothetical maximum surface of $100 \%$ \\
\hline Maturity curve & $\begin{array}{l}\text { The project is initiated in 2007, production of services starts in } 2010 \text { and reaches } \\
\text { its maximum level of services in } 2011 \text { and we have data on the metric for } 2010 \text { and } \\
2011 \text { (Table 1.3.2) }\end{array}$ \\
\hline
\end{tabular}




\begin{tabular}{|l|l|}
\hline Initiation year & 2007 \\
\hline Final year & 2032 \\
\hline
\end{tabular}

Table 1.3.1 - Assumptions and information needed for calculation of DSAYs to value the benefits of Libellule zone toward its objective of security of the WWTP's rejects

\begin{tabular}{|l|l|l|l|l|}
\hline & $\begin{array}{l}\text { Area of wetland } \\
\text { without the } \\
\text { Libellule zone }\end{array}$ & $\begin{array}{l}\text { Area of wetland in } \\
\text { the total Libellule } \\
\text { zone }\end{array}$ & $\begin{array}{l}\text { Hypothetical } \\
\text { maximum of } \\
100 \% \text { area of } \\
\text { wetland }\end{array}$ & $\begin{array}{l}\text { Value of the } \\
\text { metric }\end{array}$ \\
\hline 2010 & 0 & 6500 & 15000 & 0,43 \\
\hline 2011 & 0 & 6500 & 15000 & 0,43 \\
\hline $2012-2032$ & 0 & 6500 & 15000 & 0,43 \\
\hline
\end{tabular}

Table 1.3.2 - Maturity curve of the restoration project, values of the metric of wetland area values during time

\begin{tabular}{|c|c|c|c|c|c|}
\hline & \multicolumn{2}{|c|}{$\begin{array}{l}\text { Level of services gains associated } \\
\text { to the project }\end{array}$} & \multirow{3}{*}{$\begin{array}{l}\text { Mean gain of } \\
\text { services } \\
(3)=(1)+(2) / \\
2\end{array}$} & \multirow{3}{*}{$\begin{array}{l}\text { Discount factor } \\
(4)=(1+r)^{(2007-t)}\end{array}$} & \multirow{3}{*}{$\begin{array}{l}\text { Unitary gains } \\
\qquad(5)=(3) \times(4)\end{array}$} \\
\hline & \multicolumn{2}{|c|}{$\%$ Area of wetland / 100} & & & \\
\hline & Initial (1) & Final (2) & & & \\
\hline 2007 & 0,00 & 0,00 & 0,00 & 1,00 & 0,00 \\
\hline 2008 & 0,00 & 0,00 & 0,00 & 0,97 & 0,00 \\
\hline 2009 & 0,00 & 0,43 & 0,22 & 0,94 & 0,20 \\
\hline 2010 & 0,43 & 0,43 & 0,43 & 0,92 & 0,40 \\
\hline 2011 & 0,43 & 0,43 & 0,43 & 0,89 & 0,39 \\
\hline 2012 & 0,43 & 0,43 & 0,43 & 0,86 & 0,37 \\
\hline 2013 & 0,43 & 0,43 & 0,43 & 0,84 & 0,36 \\
\hline 2014 & 0,43 & 0,43 & 0,43 & 0,81 & 0,35 \\
\hline 2015 & 0,43 & 0,43 & 0,43 & 0,79 & 0,34 \\
\hline 2016 & 0,43 & 0,43 & 0,43 & 0,77 & 0,33 \\
\hline 2017 & 0,43 & 0,43 & 0,43 & 0,74 & 0,32 \\
\hline 2018 & 0,43 & 0,43 & 0,43 & 0,72 & 0,31 \\
\hline 2019 & 0,43 & 0,43 & 0,43 & 0,70 & 0,30 \\
\hline 2020 & 0,43 & 0,43 & 0,43 & 0,68 & 0,30 \\
\hline 2021 & 0,43 & 0,43 & 0,43 & 0,66 & 0,29 \\
\hline 2022 & 0,43 & 0,43 & 0,43 & 0,64 & 0,28 \\
\hline 2023 & 0,43 & 0,43 & 0,43 & 0,62 & 0,27 \\
\hline 2024 & 0,43 & 0,43 & 0,43 & 0,61 & 0,26 \\
\hline 2025 & 0,43 & 0,43 & 0,43 & 0,59 & 0,25 \\
\hline 2026 & 0,43 & 0,43 & 0,43 & 0,57 & 0,25 \\
\hline 2027 & 0,43 & 0,43 & 0,43 & 0,55 & 0,24 \\
\hline 2028 & 0,43 & 0,43 & 0,43 & 0,54 & 0,23 \\
\hline 2029 & 0,43 & 0,43 & 0,43 & 0,52 & 0,23 \\
\hline 2030 & 0,43 & 0,43 & 0,43 & 0,51 & 0,22 \\
\hline 2031 & 0,43 & 0,43 & 0,43 & 0,49 & 0,21 \\
\hline 2032 & 0,43 & 0,43 & 0,43 & 0,48 & 0,21 \\
\hline & & & & DSAYs & 6,92 \\
\hline
\end{tabular}


Table 1.3.3 - Calculation of the DSAYs to value the benefits of Libellule zone toward its objective of security of the WWTP's rejects

\subsection{Offset production for biodiversity measured through species richness of odonates}

\begin{tabular}{|l|l|}
\hline Project & Libellule Zone \\
\hline Objective & Offset production for biodiversity \\
\hline Metric & Indicator of the number of species of dragonflies inventoried on the site \\
\hline Reference state & Maximum of species inventoried on one area in France ${ }^{1}$ from 1970 to 2006 \\
\hline Maturity curve & $\begin{array}{l}\text { The project is initiated in 2007, production of services starts in } 2010 \text { and reaches } \\
\text { its maximum level of services in } 2011 \text { and we have data on the metric for } 2010 \text { and } \\
2011 \text { (Table 1.4.2) }\end{array}$ \\
\hline Initiation year & 2007 \\
\hline Final year & 2032 \\
\hline
\end{tabular}

Table 1.4.1 - Assumptions and information needed for calculation of DSAYs to value the benefits of Libellule zone toward its objective of offset production for biodiversity

\begin{tabular}{|c|c|c|c|c|}
\hline & $\begin{array}{l}\text { Species richness of } \\
\text { odonates without } \\
\text { the Libellule zone }\end{array}$ & $\begin{array}{l}\text { Species richness } \\
\text { of odonates on } \\
\text { the Libellule zone }\end{array}$ & $\begin{array}{l}\text { Maximum species } \\
\text { richness observed } \\
\text { on one territory in } \\
\text { France from } 1970 \\
\text { to } 2006\end{array}$ & $\begin{array}{l}\text { Value of the } \\
\text { metric }\end{array}$ \\
\hline $2007-2009$ & 3 & 0 & 70 & $-0,04$ \\
\hline 2010 & 3 & 28 & 70 & 0,36 \\
\hline 2011 & 3 & 34 & 70 & 0,44 \\
\hline $2012-2032$ & 3 & 34 & 70 & 0,44 \\
\hline
\end{tabular}

Table 1.4.24 - Maturity curve of the restoration project, values of the metric of species richness of odonates values during time

\begin{tabular}{|r|r|r|r|r|r|}
\hline & $\begin{array}{c}\text { Level of services gains associated } \\
\text { to the project }\end{array}$ & $\begin{array}{l}\text { Mean gain of } \\
\text { services }\end{array}$ & Discount factor & Unitary gains \\
\hline & $\begin{array}{c}\Delta \text { (Before/After) Species on the } \\
\text { site / Maximum species in France }\end{array}$ & $\begin{array}{r}(3)=(1)+(2) / \\
2\end{array}$ & (4)=(1+r) (2007-t) & (5)=(3)x(4) \\
\hline $\mathbf{2 0 0 7}$ & Initial (1) & Final (2) & $-0,04$ & 1,00 & $-0,04$ \\
\hline
\end{tabular}

\footnotetext{
${ }^{1}$ Société française d'odonatologie, source: INVOD, ESRI.
} 


\begin{tabular}{|c|c|c|c|c|c|}
\hline 2008 & $-0,04$ & $-0,04$ & $-0,04$ & 0,97 & $-0,04$ \\
\hline 2009 & $-0,04$ & $-0,04$ & $-0,04$ & 0,94 & $-0,04$ \\
\hline 2010 & $-0,04$ & 0,36 & 0,16 & 0,92 & 0,14 \\
\hline 2011 & 0,36 & 0,44 & 0,40 & 0,89 & 0,36 \\
\hline 2012 & 0,44 & 0,44 & 0,44 & 0,86 & 0,38 \\
\hline 2013 & 0,44 & 0,44 & 0,44 & 0,84 & 0,37 \\
\hline 2014 & 0,44 & 0,44 & 0,44 & 0,81 & 0,36 \\
\hline 2015 & 0,44 & 0,44 & 0,44 & 0,79 & 0,35 \\
\hline 2016 & 0,44 & 0,44 & 0,44 & 0,77 & 0,34 \\
\hline 2017 & 0,44 & 0,44 & 0,44 & 0,74 & 0,33 \\
\hline 2018 & 0,44 & 0,44 & 0,44 & 0,72 & 0,32 \\
\hline 2019 & 0,44 & 0,44 & 0,44 & 0,70 & 0,31 \\
\hline 2020 & 0,44 & 0,44 & 0,44 & 0,68 & 0,30 \\
\hline 2021 & 0,44 & 0,44 & 0,44 & 0,66 & 0,29 \\
\hline 2022 & 0,44 & 0,44 & 0,44 & 0,64 & 0,28 \\
\hline 2023 & 0,44 & 0,44 & 0,44 & 0,62 & 0,28 \\
\hline 2024 & 0,44 & 0,44 & 0,44 & 0,61 & 0,27 \\
\hline 2025 & 0,44 & 0,44 & 0,44 & 0,59 & 0,26 \\
\hline 2026 & 0,44 & 0,44 & 0,44 & 0,57 & 0,25 \\
\hline 2027 & 0,44 & 0,44 & 0,44 & 0,55 & 0,25 \\
\hline 2028 & 0,44 & 0,44 & 0,44 & 0,54 & 0,24 \\
\hline 2029 & 0,44 & 0,44 & 0,44 & 0,52 & 0,23 \\
\hline 2030 & 0,44 & 0,44 & 0,44 & 0,51 & 0,22 \\
\hline 2031 & 0,44 & 0,44 & 0,44 & 0,49 & 0,22 \\
\hline 2032 & 0,44 & 0,44 & 0,44 & 0,48 & 0,21 \\
\hline & & & & $\overline{D S A Y s}$ & 6,44 \\
\hline
\end{tabular}

Table 1.4.3 - Calculation of the DSAYs to value the benefits of Libellule zone toward its objective of offset production for biodiversity

\section{Environmental measures of Port 2000}

\subsection{Compensatory measures: repositories for shorebirds}

\begin{tabular}{|l|l|}
\hline Project & Environmental measures of Port 2000 \\
\hline Objective & Ecological neutrality of Port 2000 on the shorebirds in the estuary \\
\hline Metric & Abundance of shorebirds in the estuary \\
\hline Reference state & Number of shorebirds in the estuary in 1997 \\
\hline Initial state & $\begin{array}{l}\text { Difference between the number of shorebirds in } 1997 \text { and the number of } \\
\text { shorebirds in } 2005 .\end{array}$ \\
\hline Maturity curve & $\begin{array}{l}\text { Works begin in } 2001 \text { on the dune repository and } 2004 \text { on the islet. We assume that } \\
\text { we can start to measure the effects of the compensatory measures at the end on }\end{array}$ \\
\hline
\end{tabular}




\begin{tabular}{|l|l|}
\hline $\begin{array}{l}\text { the first phase of works of Port 2000, in 2005. Calculation of gain will thus begin in } \\
\text { 2005. The value of the metric is assumed using the variation of the total } \\
\text { population of shorebirds on the estuary. From 2005, all variation of shorebird } \\
\text { population is associated to the compensatory measure. Using the work of Aulert et } \\
\text { al. (2009) we know the variation of the population of shorebirds from } 1997 \text { to } \\
2008 . \text { We assume that after } 2007, \text { the level of service will reach the } 1997 \text { baseline } \\
\text { in } 2010 \text { with a linear growth. }\end{array}$ \\
\hline Initiation year & $\begin{array}{l}1997 \text { is the reference year associated to the impact } \\
\text { Final year }\end{array}$ \\
\hline
\end{tabular}

Table 2.1.1 - Assumptions and information needed for calculation of DSAYs to value the benefits of repositories for shorebirds in the Seine estuary

\begin{tabular}{|l|l|l|l|l|}
\hline & $\begin{array}{l}\text { Number of } \\
\text { shorebirds on the } \\
\text { estuary }\end{array}$ & $\begin{array}{l}\text { Number of } \\
\text { shorebirds without } \\
\text { the project (2004) }\end{array}$ & $\begin{array}{l}\text { Number of } \\
\text { shorebirds on the } \\
\text { estuary in 1997 }\end{array}$ & $\begin{array}{l}\text { metric } \\
\text { (20) of the }\end{array}$ \\
\hline 2004 & 7000 & 7000 & 16000 & 0 \\
\hline 2006 & 7000 & 7000 & 16000 & 0 \\
\hline 2007 & 7000 & 7000 & 16000 & 0 \\
\hline 2008 & 5000 & 7000 & 16000 & $-0,13$ \\
\hline 2009 & 8700 & 7000 & 16000 & 0,11 \\
\hline $2010-2030$ & 12400 & 7000 & 16000 & 0,34 \\
\hline
\end{tabular}

Table 2.1.25 - Maturity curve of the restoration project, values of the metric of abundance of shorebirds on the estuary

\begin{tabular}{|c|c|c|c|c|c|}
\hline & \multicolumn{2}{|c|}{$\begin{array}{c}\text { Level of services gains associated } \\
\text { to the project }\end{array}$} & $\begin{array}{l}\text { Mean gain of } \\
\text { services }\end{array}$ & Discount factor & Unitary gains \\
\hline & \multicolumn{2}{|c|}{$\begin{array}{c}\text { Number of birds due to action / } \\
\text { Number of birds in } 1997\end{array}$} & \multirow[t]{2}{*}{$\begin{array}{c}(3)=(1)+(2) / \\
2\end{array}$} & \multirow[t]{2}{*}{$(4)=(1+r)^{(2005-t)}$} & \multirow[t]{2}{*}{$(5)=(3) \times(4)$} \\
\hline & Initial (1) & Final (2) & & & \\
\hline 2005 & 0,00 & 0,00 & 0,00 & 0,79 & 0,00 \\
\hline 2006 & 0,00 & 0,00 & 0,00 & 0,77 & 0,00 \\
\hline 2007 & 0,00 & $-0,13$ & $-0,06$ & 0,74 & 0,00 \\
\hline 2008 & $-0,13$ & 0,11 & $-0,01$ & 0,72 & 0,00 \\
\hline 2009 & 0,11 & 0,34 & 0,22 & 0,70 & 0,00 \\
\hline 2010 & 0,34 & 0,56 & 0,45 & 0,68 & 0,01 \\
\hline 2011 & 0,56 & 0,56 & 0,56 & 0,66 & 0,01 \\
\hline 2012 & 0,56 & 0,56 & 0,56 & 0,64 & 0,01 \\
\hline 2013 & 0,56 & 0,56 & 0,56 & 0,62 & 0,01 \\
\hline 2014 & 0,56 & 0,56 & 0,56 & 0,61 & 0,01 \\
\hline 2015 & 0,56 & 0,56 & 0,56 & 0,59 & 0,01 \\
\hline
\end{tabular}




\begin{tabular}{|r|r|r|r|r|r|}
\hline 2016 & 0,56 & 0,56 & 0,56 & 0,57 & 0,01 \\
\hline 2017 & 0,56 & 0,56 & 0,56 & 0,55 & 0,01 \\
\hline 2018 & 0,56 & 0,56 & 0,56 & 0,54 & 0,01 \\
\hline 2019 & 0,56 & 0,56 & 0,56 & 0,52 & 0,01 \\
\hline 2020 & 0,56 & 0,56 & 0,56 & 0,51 & 0,01 \\
\hline 2021 & 0,56 & 0,56 & 0,56 & 0,49 & 0,01 \\
\hline 2022 & 0,56 & 0,56 & 0,56 & 0,48 & 0,01 \\
\hline 2023 & 0,56 & 0,56 & 0,56 & 0,46 & 0,01 \\
\hline 2024 & 0,56 & 0,56 & 0,56 & 0,45 & 0,01 \\
\hline 2025 & 0,56 & 0,56 & 0,56 & 0,44 & 0,01 \\
\hline 2026 & 0,56 & 0,56 & 0,56 & 0,42 & 0,01 \\
\hline 2027 & 0,56 & 0,56 & 0,56 & 0,41 & 0,00 \\
\hline 2028 & 0,56 & 0,56 & 0,56 & 0,40 & 0,00 \\
\hline 2029 & 0,56 & 0,56 & 0,56 & 0,39 & 0,00 \\
\hline 2030 & 0,56 & 0,56 & 0,56 & 0,38 & 0,00 \\
\hline & & & DSAYs & 0,131 \\
\hline
\end{tabular}

Table 2.1.3 - Calculation of the DSAYs to value the benefits of repositories for shorebirds in the Seine estuary

\subsection{Accompanying measures : rehabilitation of mudflats}

\begin{tabular}{|l|l|}
\hline Project & Environmental measures of Port 2000 \\
\hline Objective & Rehabilitation of 100 ha of mudflat \\
\hline Metric & Surface of mudflats \\
\hline Reference state & Objective of mudflat rehabilitation (100 ha) \\
\hline Initial state & Null \\
\hline Maturity curve & $\begin{array}{l}\text { Project is associated to the rehabilitation of } 60 \text { ha of mudflats in 2012. Using the } \\
\text { work of Aulert et al. (2009), we know that the project can be associated to the } \\
\text { rehabilitation of } 45 \text { ha in 2008. Works ended in 2005, we assume linear growth of } \\
\text { the surface of mudflat from } 2006 \text { to } 2008 \text { (45 ha) and from } 2008 \text { to } 2012 \text { (60 ha). }\end{array}$ \\
\hline Initiation year & 2005 is the beginning of the works \\
\hline Final year & 2032 \\
\hline
\end{tabular}

Table 2.2.1 - Assumptions and information needed for calculation of DSAYs to value the benefits of the rehabilitation of mudflats in the Seine estuary

\begin{tabular}{|l|l|l|l|}
\hline & $\begin{array}{l}\text { Surface of mudflats } \\
\text { that appeared }\end{array}$ & $\begin{array}{l}\text { Objective of 100 ha of } \\
\text { rehabilitation project }\end{array}$ & Value of the metric \\
\hline 2005 & 0 & 100 & 0 \\
\hline 2006 & 15 & 100 & 0,15 \\
\hline 2007 & 30 & 100 & 0,3 \\
\hline 2008 & 45 & 100 & 0,45 \\
\hline
\end{tabular}




\begin{tabular}{|l|l|l|l|}
\hline 2009 & 48,75 & 100 & 0,4875 \\
\hline 2010 & 52,5 & 100 & 0,525 \\
\hline 2011 & 56,25 & 100 & 0,5625 \\
\hline $2012-2030$ & 60 & 100 & 0,6 \\
\hline
\end{tabular}

Table 2.2.2 - Maturity curve of the restoration project, values of the metric of surface of mudflats rehabilitated

\begin{tabular}{|c|c|c|c|c|c|}
\hline & \multicolumn{2}{|c|}{$\begin{array}{l}\text { Level of services gains associated } \\
\text { to the project }\end{array}$} & \multirow{3}{*}{$\begin{array}{l}\text { Mean gain of } \\
\text { services } \\
(3)=(1)+(2) / \\
2\end{array}$} & \multirow{3}{*}{$\begin{array}{l}\text { Discount factor } \\
(4)=(1+r)^{(2005-t)}\end{array}$} & \multirow{3}{*}{$\begin{array}{l}\text { Unitary gains } \\
\qquad(5)=(3) \times(4)\end{array}$} \\
\hline & \multicolumn{2}{|c|}{$\begin{array}{l}\text { Area of mudflat due to action / } \\
\text { Area of mudflats expected }\end{array}$} & & & \\
\hline & Initial (1) & Final (2) & & & \\
\hline 2005 & 0,00 & 0,00 & 0,00 & 1,00 & 0,00 \\
\hline 2006 & 0,00 & 0,15 & 0,08 & 0,97 & 0,07 \\
\hline 2007 & 0,15 & 0,30 & 0,23 & 0,94 & 0,21 \\
\hline 2008 & 0,30 & 0,45 & 0,38 & 0,92 & 0,34 \\
\hline 2009 & 0,45 & 0,49 & 0,47 & 0,89 & 0,42 \\
\hline 2010 & 0,49 & 0,53 & 0,51 & 0,86 & 0,44 \\
\hline 2011 & 0,53 & 0,56 & 0,54 & 0,84 & 0,46 \\
\hline 2012 & 0,56 & 0,60 & 0,58 & 0,81 & 0,47 \\
\hline 2013 & 0,60 & 0,60 & 0,60 & 0,79 & 0,47 \\
\hline 2014 & 0,60 & 0,60 & 0,60 & 0,77 & 0,46 \\
\hline 2015 & 0,60 & 0,60 & 0,60 & 0,74 & 0,45 \\
\hline 2016 & 0,60 & 0,60 & 0,60 & 0,72 & 0,43 \\
\hline 2017 & 0,60 & 0,60 & 0,60 & 0,70 & 0,42 \\
\hline 2018 & 0,60 & 0,60 & 0,60 & 0,68 & 0,41 \\
\hline 2019 & 0,60 & 0,60 & 0,60 & 0,66 & 0,40 \\
\hline 2020 & 0,60 & 0,60 & 0,60 & 0,64 & 0,39 \\
\hline 2021 & 0,60 & 0,60 & 0,60 & 0,62 & 0,37 \\
\hline 2022 & 0,60 & 0,60 & 0,60 & 0,61 & 0,36 \\
\hline 2023 & 0,60 & 0,60 & 0,60 & 0,59 & 0,35 \\
\hline 2024 & 0,60 & 0,60 & 0,60 & 0,57 & 0,34 \\
\hline 2025 & 0,60 & 0,60 & 0,60 & 0,55 & 0,33 \\
\hline 2026 & 0,60 & 0,60 & 0,60 & 0,54 & 0,32 \\
\hline 2027 & 0,60 & 0,60 & 0,60 & 0,52 & 0,31 \\
\hline 2028 & 0,60 & 0,60 & 0,60 & 0,51 & 0,30 \\
\hline 2029 & 0,60 & 0,60 & 0,60 & 0,49 & 0,30 \\
\hline 2030 & 0,60 & 0,60 & 0,60 & 0,48 & 0,29 \\
\hline & & & & DSAYs & 9,12 \\
\hline
\end{tabular}

Table 2.2.3 - Calculation of the DSAYs to value the benefits of the rehabilitation of mudflats

\section{Kervigen marsh}

\begin{tabular}{|l|l|}
\hline Project & Kervigen marsh \\
\hline Objective & Reduction of 50 kg nitrate per year through restoration of marshes \\
\hline
\end{tabular}




\begin{tabular}{|l|l|}
\hline Metric & Absorbed nitrate \\
\hline Reference state & Nitrate reduction objective (50 tons per year) \\
\hline Initial state & Absorbed nitrate without the marsh (null) \\
\hline Maturity curve & $\begin{array}{l}\text { Purification performance associated to the latest measures in 2008, it gives a } \\
\text { performance between } 2 \text { and } 4 \mathrm{~kg} \text { per day per hectare, we present result for the } \\
\text { lowest value. }\end{array}$ \\
\hline Initiation year & 2010 is the beginning of the works \\
\hline Final year & 2035 \\
\hline
\end{tabular}

Table 3.1.1 - Assumptions and information needed for calculation of DSAYs to value the benefits of the rehabilitation of Kervigen marsh

\begin{tabular}{|l|l|l|l|}
\hline & $\begin{array}{l}\text { Performances of } \\
\text { nitrate mitigation } \\
\text { (t/year/ha) }\end{array}$ & $\begin{array}{l}\text { Objective of mitigation } \\
\text { of } 50 \mathrm{t} / \text { year }\end{array}$ & Value of the metric \\
\hline $2012-2030$ & 0,22 & 100 & 0,044 \\
\hline
\end{tabular}

Table 3.1.2 - Maturity curve of the restoration project, values of the metric of nitrate mitigation performance

\begin{tabular}{|c|c|c|c|c|c|}
\hline & \multirow{2}{*}{\multicolumn{2}{|c|}{$\begin{array}{c}\text { Level of services gains associated } \\
\text { to the project } \\
\text { Nitrate mitigation capacity of the } \\
\text { marsh / Total objective of } \\
\text { mitigation }\end{array}$}} & \multirow{3}{*}{$\begin{array}{l}\begin{array}{l}\text { Mean gain of } \\
\text { services }\end{array} \\
(3)=(1)+(2) / \\
2\end{array}$} & \multirow{3}{*}{$\begin{array}{l}\text { Discount factor } \\
(4)=(1+r)^{(2012-t)}\end{array}$} & \multirow{3}{*}{$\begin{array}{l}\text { Unitary gains } \\
\qquad(5)=(3) \times(4)\end{array}$} \\
\hline & & & & & \\
\hline & Initial (1) & Final (2) & & & \\
\hline 2012 & 0 & \begin{tabular}{|r|}
0,0044 \\
\end{tabular} & 0,0 & 1,00 & 0,002 \\
\hline 2013 & 0,0044 & 0,0044 & 0,0 & 0,97 & 0,004 \\
\hline 2014 & 0,0044 & 0,0044 & 0,0 & 0,94 & 0,004 \\
\hline 2015 & 0,0044 & 0,0044 & 0,0 & 0,92 & 0,004 \\
\hline 2016 & 0,0044 & 0,0044 & 0,0 & 0,89 & 0,004 \\
\hline 2017 & 0,0044 & 0,0044 & 0,0 & 0,86 & 0,004 \\
\hline 2018 & 0,0044 & 0,0044 & 0,0 & 0,84 & 0,004 \\
\hline 2019 & 0,0044 & 0,0044 & 0,0 & 0,81 & 0,004 \\
\hline 2020 & 0,0044 & 0,0044 & 0,0 & 0,79 & 0,003 \\
\hline 2021 & 0,0044 & 0,0044 & 0,0 & 0,77 & 0,003 \\
\hline 2022 & 0,0044 & 0,0044 & 0,0 & 0,74 & 0,003 \\
\hline 2023 & 0,0044 & 0,0044 & 0,0 & 0,72 & 0,003 \\
\hline 2024 & 0,0044 & 0,0044 & 0,0 & 0,70 & 0,003 \\
\hline 2025 & 0,0044 & 0,0044 & 0,0 & 0,68 & 0,003 \\
\hline 2026 & 0,0044 & 0,0044 & 0,0 & 0,66 & 0,003 \\
\hline 2027 & 0,0044 & 0,0044 & 0,0 & 0,64 & 0,003 \\
\hline 2028 & 0,0044 & 0,0044 & 0,0 & 0,62 & 0,003 \\
\hline 2029 & 0,0044 & 0,0044 & 0,0 & 0,61 & 0,003 \\
\hline 2030 & 0,0044 & 0,0044 & 0,0 & 0,59 & 0,003 \\
\hline 2031 & 0,0044 & 0,0044 & 0,0 & 0,57 & 0,003 \\
\hline 2032 & 0,0044 & 0,0044 & 0,0 & 0,55 & 0,002 \\
\hline 2033 & 0,0044 & 0,0044 & 0,0 & 0,54 & 0,002 \\
\hline 2034 & 0,0044 & 0,0044 & 0,0 & 0,52 & 0,002 \\
\hline
\end{tabular}




\begin{tabular}{|r|r|r|r|r|r|}
\hline 2035 & 0,0044 & 0,0044 & 0,0 & 0,51 & 0,002 \\
\hline 2036 & 0,0044 & 0,0044 & 0,0 & 0,49 & 0,002 \\
\hline 2037 & 0,0044 & 0,0044 & 0,0 & 0,48 & 0,002 \\
\hline
\end{tabular}

Table 3.1.3 - Calculation of the DSAYs to value the benefits of the rehabilitation of Kervigen marsh

\section{Vurpillères stream}

\begin{tabular}{|c|c|}
\hline Project & Vurpillères stream \\
\hline Objective & Ecological restoration of the site to its initial state \\
\hline Metric & Species richness of plecoptera, trichoptera and ephemeroptera \\
\hline Reference state & Species richness in 2007 \\
\hline Initial state & Number of species before restoration \\
\hline Maturity curve & $\begin{array}{l}\text { According to the work of Redding [2009], we select the number of observed } \\
\text { species in 1993, 1998, } 2002 \text { and 2007, we assume linear growth between } \\
\text { observations. }\end{array}$ \\
\hline Initiation year & 1997 is the beginning of the works \\
\hline Final year & 2022 \\
\hline
\end{tabular}

Table 4.1.1 - Assumptions and information needed for calculation of DSAYs to value the benefits of the rehabilitation of Kervigen marsh

\begin{tabular}{|l|l|l|l|l|}
\hline & $\begin{array}{l}\text { Species richness } \\
\text { without project }\end{array}$ & $\begin{array}{l}\text { Species richness } \\
\text { on the site }\end{array}$ & $\begin{array}{l}\text { Species richness } \\
\text { at reference } \\
(1967)\end{array}$ & $\begin{array}{l}\text { Value of the } \\
\text { metric }\end{array}$ \\
\hline 1997 & 25 & 25 & 48 & 0 \\
\hline 1998 & 25 & 25 & 48 & 0 \\
\hline 1999 & 25 & 29 & 48 & 0,08 \\
\hline 2000 & 25 & 29 & 48 & 0,08 \\
\hline 2001 & 25 & 30 & 48 & 0,10 \\
\hline 2002 & 25 & 30 & 48 & 0,10 \\
\hline 2003 & 25 & 31 & 48 & 0,13 \\
\hline 2004 & 25 & 34 & 48 & 0,19 \\
\hline 2005 & 25 & 37 & 48 & 0,25 \\
\hline 2006 & 25 & 40 & 48 & 0,31 \\
\hline 2007 & 25 & 44 & 48 & 0,40 \\
\hline $2008-2018$ & 25 & 48 & 48 & 0,48 \\
\hline
\end{tabular}


Table 4.1.2 - Maturity curve of the restoration project, values of the metric of species richness

\begin{tabular}{|c|c|c|c|c|c|}
\hline & \multirow{2}{*}{\multicolumn{2}{|c|}{$\begin{array}{l}\text { Level of services gains associated } \\
\text { to the project } \\
\Delta \text { (Input/Output) Dissolved oxygen } \\
\text { / Dissolved oxygen in the Or } \\
\text { lagoon }\end{array}$}} & \multirow{3}{*}{$\begin{array}{l}\text { Mean gain of } \\
\text { services } \\
(3)=(1)+(2) / \\
2\end{array}$} & \multirow{3}{*}{$\begin{array}{l}\text { Discount factor } \\
(4)=(1+r)^{(2012-t)}\end{array}$} & \multirow{3}{*}{$\begin{array}{l}\text { Unitary gains } \\
\qquad(5)=(3) \times(4)\end{array}$} \\
\hline & & & & & \\
\hline & Initial (1) & Final (2) & & & \\
\hline 1997 & 0,00 & 0,00 & 0,00 & 1,00 & 0,00 \\
\hline 1998 & 0,00 & 0,08 & 0,04 & 0,97 & 0,04 \\
\hline 1999 & 0,08 & 0,08 & 0,08 & 0,94 & 0,08 \\
\hline 2000 & 0,08 & 0,10 & 0,09 & 0,92 & 0,09 \\
\hline 2001 & 0,10 & 0,10 & 0,10 & 0,89 & 0,09 \\
\hline 2002 & 0,10 & 0,13 & 0,11 & 0,86 & 0,10 \\
\hline 2003 & 0,13 & 0,19 & 0,16 & 0,84 & 0,13 \\
\hline 2004 & 0,19 & 0,25 & 0,22 & 0,81 & 0,18 \\
\hline 2005 & 0,25 & 0,31 & 0,28 & 0,79 & 0,22 \\
\hline 2006 & 0,31 & 0,40 & 0,35 & 0,77 & 0,27 \\
\hline 2007 & 0,40 & 0,48 & 0,44 & 0,74 & 0,33 \\
\hline 2008 & 0,48 & 0,48 & 0,48 & 0,72 & 0,35 \\
\hline 2009 & 0,48 & 0,48 & 0,48 & 0,70 & 0,34 \\
\hline 2010 & 0,48 & 0,48 & 0,48 & 0,68 & 0,33 \\
\hline 2011 & 0,48 & 0,48 & 0,48 & 0,66 & 0,32 \\
\hline 2012 & 0,48 & 0,48 & 0,48 & 0,64 & 0,31 \\
\hline 2013 & 0,48 & 0,48 & 0,48 & 0,62 & 0,30 \\
\hline 2014 & 0,48 & 0,48 & 0,48 & 0,61 & 0,29 \\
\hline 2015 & 0,48 & 0,48 & 0,48 & 0,59 & 0,28 \\
\hline 2016 & 0,48 & 0,48 & 0,48 & 0,57 & 0,27 \\
\hline 2017 & 0,48 & 0,48 & 0,48 & 0,55 & 0,27 \\
\hline 2018 & 0,48 & 0,48 & 0,48 & 0,54 & 0,26 \\
\hline 2019 & 0,48 & 0,48 & 0,48 & 0,52 & 0,25 \\
\hline 2020 & 0,48 & 0,48 & 0,48 & 0,51 & 0,24 \\
\hline 2021 & 0,48 & 0,48 & 0,48 & 0,49 & 0,24 \\
\hline 2022 & 0,48 & 0,48 & 0,48 & 0,48 & 0,23 \\
\hline & & & & DSAYs & 5,79 \\
\hline
\end{tabular}

Table 4.1.3 - Calculation of the DSAYs to value the benefits of the restoration of Vurpillères stream

\section{Calculation of cost of projects}

For each project cost are calculated based on the fixed cost of project and the yearly variable cost associated to monitoring and management. Results are summarized in table 5.1

\begin{tabular}{|l|l|l|l|l|}
\hline Project & Fixed cost $\left(. \mathrm{ha}^{-1}\right)$ & $\begin{array}{l}\text { Variable cost }(. \text { ha } \\
1\end{array}$ & $\begin{array}{l}\text { Variable cost on } \\
25 \text { years }\left(. \mathrm{ha}^{-1}\right)\end{array}$ & Total cost $\left(. \mathrm{ha}^{-1}\right)$ \\
\hline Libellule $^{\circledR}$ Zone & 233,000 & 60,000 & $1,105,000$ & $1,338,000$ \\
\hline $\begin{array}{l}\text { Environmental } \\
\text { measures of Port }\end{array}$ & 77,000 & 0 & 0 & 77,000 \\
\hline
\end{tabular}




\begin{tabular}{|c|c|c|c|c|}
\hline $\begin{array}{l}2000 \text { - Mudflats } \\
\text { rehabilitation }\end{array}$ & & & & \\
\hline $\begin{array}{l}\text { Environmental } \\
\text { measures of Port } \\
2000 \text { - } \\
\text { Repositories }\end{array}$ & $\begin{array}{l}\text { Dune repository } \\
(97 \% \text { in } 1 \text { ha): } \\
42,200 \\
\text { Islet repository } \\
\text { ( } 3 \% \text { in } 1 \text { ha): } \\
5,300,000\end{array}$ & 0 & 0 & 213,000 \\
\hline Kervigen marsh & 8,600 & 273 & 5,000 & 13,600 \\
\hline $\begin{array}{l}\text { Vurpillères } \\
\text { stream }\end{array}$ & 10,600 & 0 & 0 & 10,600 \\
\hline
\end{tabular}

Tableau 5.1 - Calculation of costs per hectare for each project 